WAPD-TM-182

AEC RESEARCH AND DEVELOPMENT REPORT

\title{
MASTER
}

\section{DEFLECTIONS AND LOAD DISTRIBUTIONS IN LINEAR ELASTIC STRUCTURES-CTAC AND MODE CODES}

JANUARY 1960

CONTRACT AT-11-1-GEN-14

BETTIS ATOMIC POWER LABORATORY, PITTSBURGH, PA., OPERATED FOR THE U.S. ATOMIC ENERGY COMMISSION BY WESTINGHOUSE ELECTRIC CORPORATION 


\section{DISCLAIMER}

This report was prepared as an account of work sponsored by an agency of the United States Government. Neither the United States Government nor any agency Thereof, nor any of their employees, makes any warranty, express or implied, or assumes any legal liability or responsibility for the accuracy, completeness, or usefulness of any information, apparatus, product, or process disclosed, or represents that its use would not infringe privately owned rights. Reference herein to any specific commercial product, process, or service by trade name, trademark, manufacturer, or otherwise does not necessarily constitute or imply its endorsement, recommendation, or favoring by the United States Government or any agency thereof. The views and opinions of authors expressed herein do not necessarily state or reflect those of the United States Government or any agency thereof. 


\section{DISCLAIMER}

Portions of this document may be illegible in electronic image products. Images are produced from the best available original document. 
UC-80: Reactors-General TID-4500 (15th Ed.)

\title{
DEFLECTIONS AND LOAD DISTRIBUTIONS IN LINEAR ELASTIC STRUCTURES-CTAC AND MODE CODES
}

\author{
Carl M. Friedrich
}

January 1960

Contract AT-11-1-GEN-14

Price $\$ 1.50$

Available from the Office of Technical Services,

Department of Commerce,

Washington 25, D. C.

NOTE

This document is an interim memorandum prepared primarily for internal reference and does not represent a final expression of the opinion of Westinghouse. When this memorandum is distributed externally, it is with the express understanding that Westinghouse makes no representation as to. completeness, accuracy, or usability of information contained therein.

\section{BETTIS ATOMIC POWER LABORATORY PITTSBURGH, PENNSYLVANIA


Manager, Pittsburgh Naval Reactors Operations Office, AEC Carnegie Institute of Technology, C. Zorowski

Westinghouse Patent Department, East Pittsburgh, D. J. Smith

Westinghouse Research Laboratories, N. C. Small

$\begin{array}{r}3 \\ 1 \\ 1 \\ 1 \\ \hline 591\end{array}$

\section{LÉGAL NOTICE}

This report was prepared as an account of Government sponsored work. Heither the United States, nor the Commission, nor any person afting on behalf of the Commission:

A. Makes any warranty or representation, expressed or implied, with respect to the accuracy, completeness, or usefulness of the information contained in this report, or that the use of any information, apparatus, method, or process disclosed in this report may not infringe privately owned rights; or

B. Assumes any liabilities with resoect to the use nf, or for damages resulting from the use of any information, apparatus, method, or process disclosed in this report.

- As used in the above, "person acting on behalf of the Commission" includes any employe or contractor of the commission, or employe of such contractor, to the extent that such employe nr contractor of the commicsion, or emoloye of auch contiratur prepares, diseomlnates, or provides access to; any information pursuant to his employment or contract with the Commission, or his employment with such contractor. 
I. INTRODUCTION

II. FORCE, DEFLECTION, AND ENERGY

Page No.

A. Force

B. Working Deflection

Reciprocal Theorem

Castigliano's Theorem

Structure Position

C. Strain Energy

Beam Energy

Cantilever Beam

Simple Support Beam

Transformation from Cantilever to Simple Support

III. SYSTEMATIC CALCULATION

A. Cantilever Influence Coefficients

Energy

B. Simple Support

CTAC Rule

Flexibility

IV. APPLICATION OF CTAC

A. Structure in WAPD-115 13

Given Data 13

Flexibility of a Subdivided Free Body $\quad 15$

Total Flexibility 16

Redundant Load Calculation 18

Systematic Load Calculation $\quad . \quad \cdots$

B. S0207 Code (CTAC and MODE) 21

Discussion $\quad 21$

Arrangement of Decks $\quad 21$

CTAC without MODE $\quad \cdot \quad 21$

CTAC and MODE 21

MODE Alone $\quad$ - 22

Input Cards

Transfer Cards $\quad 22$

Data Card Format $\quad$. 22

CTAC Data Deck (Input) 24

MODE Data Deck (Input) $\quad \cdot \quad 26$

$\begin{array}{ll}\text { Output Cards } & 27 \\ & \end{array}$

Output Card Format $\quad 27$

CTAC Output Deck $\quad 28$

MODE Mitput. Der.k 29

Sample Problem Using Structure in WA P.D-115 30

Printout of Cards $\quad 30$

Results $\quad 30$

Sample Problem Cards $\quad 30$

$\begin{array}{ll}\text { ACKNOWLEDGMENT } & \mathbf{4 4}\end{array}$

REFERENCES $\quad-44$ 
Since the stress analysis of a complicated statically indeterminate structure involves the handling of many simultaneous equations, the 50207 code for the IBM-650 was developed at Bettis to solve this problem by the use of matrix transformations. The code has two parts, each with a title: (a) the CTAC code gives stresses, deflections, and reactions; and (b) the MODE code calculates natural frequencies and modes of vibration. As an aid to users of the code, a review is given of the elasticity and matrix transformation theory utilized in this code.

\title{
DEFLECTIONS AND LOAD DISTRIBUTIONS IN LINEAR ELASTIC STRUCTURES-CTAC AND MODE CODES
}

\author{
C. M. Friedrich
}

\section{INTRODUCTION}

The determination of forces and deflections for.complicated statically indeterminate structures involves the handling of many simultaneous equations. In order to keep track of the variables and equations in successive steps of calculations, a systematic routine is needed.

One such routine was developed by Gabriel Kron (Ref 1) for electrical engineering problems. This routine of matrix transformations was adapted by Borge Langefors (Ref 2) for elastic struclure problems. Kron (Ref 3) later extended Langefors' adaptations to take care of nonlinear plastic deformation. A thorough and detailed discussion with applications on energy principles of structure analysis, including the effects of temperature and nonlinear stress-strain relations, was made by J. H. Argyris (Ref 4).

The purpooco of thie report are:

1) To give a simplified explanation of the matrix transformation method for linear elastic structures (preceded by a review of elementary concepts and theorems in elasticity which are used in the method).

2) To show the application of this method in determining influence coefficients of structures that may be redundant.

3) To show how this method is applied in the CTAC code (first part of the Wolontis-650. code S0207).

4) To show how the MODE code (second part of code S0207) can be used to determine the modes of :vibration of an elastic, structure. 


\section{FORCE, DEFLECTION, AND ENERGY}

\section{A. Force}

The basis of any engineering analysis of a complicated structure is the free body diagram of each component. Every force or moment shown on the free body diagram is actually a system of forces and/or moments which are in equilibrium with each other.

Conventional foundation shading lines on a free body diagram are used to indicate the remainder: of the force system acting on the body to retain it in equilibrium. For example, the forces shown acting on the structures in Fig. $1 \mathrm{~A}$ are actually the force systems shown in Fig. $1 \mathrm{~B}$.

The fundamental process of analysis involves the subdividing of the free body diagram of a complicated structure into two or more free bodies of simpler geometry, as shown in Fig. 2. Care must be taken to have the force system on each subdivided body in self-equilibrium and to have the force systems on the subdivided free bodies actually equivalent to the force system on the original free body, in regard to force and moment distribution throughout the body.

A. FORCES ON STRUCTURES
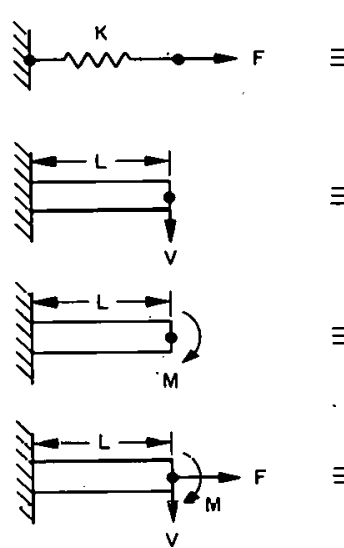

$\equiv$

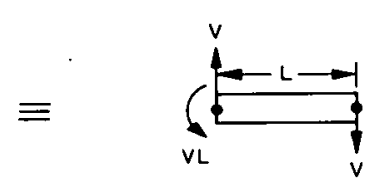

fla. I Free body tquilithrium
A nRIŞINGAL FREE DOOY

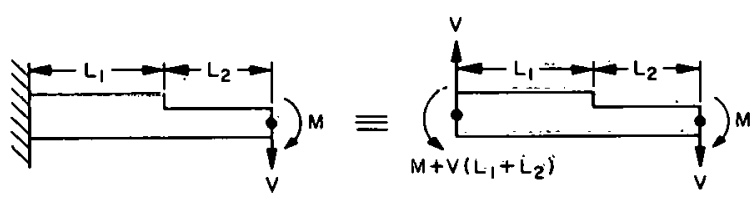

B. SUBDIVIDED FREE BODIES

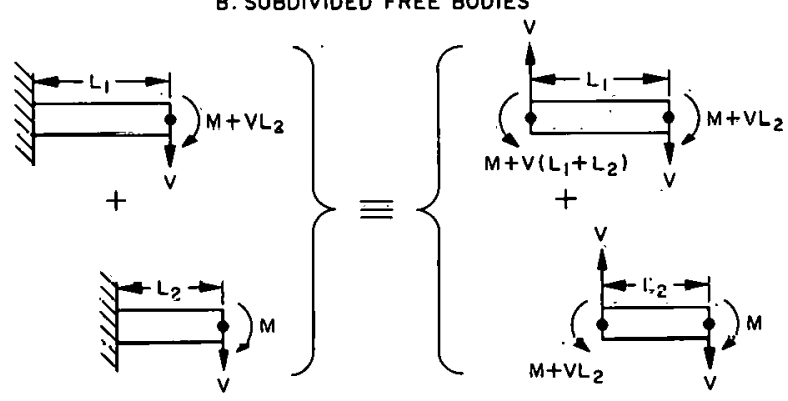

Fig. 2 Subdivision of Free Bodies

In this treatment a force or force system may be labeled by one of the forces or moments in the system. Thus, a "force" may actually be a true force or even a bending moment or a torque.

B. Working Deflection

\section{Reciprocal Theorem}

Considering three forces $F_{1}, F_{2}$, and $F_{3}$ acting on a structure, if the structure is assumcd linear-elastic, the working deflection of each force is a linear function of all forces. That is,

$$
\begin{aligned}
& D_{F 1}=A_{11} F_{1}+A_{12} F_{2}+A_{13} F_{3}, \\
& D_{F 2}=A_{21} F_{1}+A_{22} F_{2}+A_{23} F_{3},
\end{aligned}
$$

and

$$
D_{F 3}=A_{31} F_{1}+A_{32} F_{2}+A_{33} F_{3}
$$

where

$D_{F i}=$ working deflection of $F_{i}$,

$A_{i j}=$ influence deflection coefficient, equal to the working deflection of $F_{i}$ produced by the unit load $F_{j}=1$, and 
$i, j=$ subscripts having values 1,2 , or 3 .

A very important relationship concerning these influence coefficients can be determined by changing the order of load applications and comparing final strain energies. The change in strain energy when loads change on the linear elastic structure is, by definition of working deflections,

$$
d U^{\prime}=F_{1}^{\prime} d D_{F 1}^{\prime}+F_{2}^{\prime} d D_{F 2}^{\prime}+F_{3}^{\prime} d D_{F 3}^{\prime} \text {, }
$$

where $U=$ strain energy of the structure and a prime is used to denote the value of any quantity during a change. Substitution of the deflections of Eqs (1) and (2) gives

$$
\begin{aligned}
d U^{\prime}= & F_{i}^{\prime}\left(A_{11} d F_{i}^{\prime}+A_{12} d \cdot F_{2}^{\prime}+A_{13} d F_{3}^{\prime}\right) \\
+ & F_{2}^{\prime}\left(A_{21} d F_{i}^{\prime}+A_{22} d F_{2}^{\prime}+A_{23} d F_{3}^{\prime}\right) \\
& +F_{3}^{\prime}\left(A_{31} d F_{i}^{\prime}+A_{32} d F_{2}^{\prime}+A_{33} d F_{3}^{\prime}\right)
\end{aligned}
$$

First, allow a force, say $F_{1}^{\prime}$, to increase from zero to full value $F_{1}$ while the other forces remain zero. The strain energy of the structure becomes

$$
U=\int_{0}^{F_{1}}\left[F_{1}^{\prime}\left(A_{11} d F_{1}^{\prime}+0+0\right)+0+0\right]
$$

or

$$
\mathrm{U}=\left(\mathrm{A}_{11} / 2\right) \mathrm{F}_{1}^{2}
$$

Next, allow another force, say $F_{2}^{\prime}$, to increase from zero to full value $F_{2}$ while the other forces remain unchanged. The strain energy of the structure is increased to become

$$
U=\left(A_{11} / 2\right) \cdot F_{1}^{2}+\int_{0}^{F_{2}}\left[F_{1}\left(0+A_{12} d F_{2}^{\prime}+0\right)+F_{2}^{\prime}\left(0+A_{22} d F_{2}^{\prime}+0\right)+0\right]
$$

or

$$
U=\left(A_{11} / 2\right) F_{1}^{2}+\left(A_{12}\right) F_{1} F_{2}+\left(A_{22} / 2\right) F_{2}^{2}
$$

If the order of load application were reversed, the total strain energy would be

$$
U=\left(A_{22} / 2\right) F_{2}^{2}+\left(A_{21}\right) F_{2} F_{1}+\left(A_{11} / 2\right) F_{1}^{2}
$$

Since the final strain energy of a linear-elastic structure depends only on the final shape of the structure as determined by the working deflections and the final working deflections depend only on the final forces according to Ëqs (1), then the strain energy should be independent of the order of load applications. Equating the energies of Eqs (4) and (5) leads to the result that $A_{21}=A_{12}$.

This very important result states that the working deflection of one force produced by a unit value of a second force equals the working deflection of the second force produced by a unit value of the first force. This relationship is known as the Reciprocal Theorem. In general,

$$
A_{i j}=A_{j i}
$$

for all values of $i$ and $j$.

Castigliano's Theorem

A useful generalization of the energy integral can be obtained by application of the Reciprocal Theorem. Corresponding to Eqs (1), the generalized deflection equation is

$$
D_{F i}=\Sigma_{j} A_{i j} F_{j}
$$


and the generalized sträin ene $r$ gy equation is

$$
U=\int\left(\Sigma_{i} F_{i} d D_{F i}\right)
$$

Substitution of $D_{F i}$ from $E q(7)$ gives

$$
U=\int\left(\Sigma_{i} F_{i} \Sigma_{j} A_{i j} d F_{j}\right)=\int\left(\Sigma_{i j} F_{i} A_{i j} d F_{j}\right) \text {. }
$$

Now, by using Eq (6),

$$
\begin{aligned}
U & =\frac{1}{2} \int\left(\Sigma_{i j} F_{i} A_{i j} d F_{j}\right)+\frac{1}{2} \int\left(\Sigma_{i j} F_{j} A_{i j} d \ddot{F}_{i}\right) \\
& =\frac{1}{2} \int \Sigma_{i j} A_{i j}\left(F_{i} d F_{j}+F_{j} d F_{i}\right) \\
& =\frac{1}{2} \int \Sigma_{i j} A_{i j} d\left(\dot{F}_{i} F_{j}\right) ;
\end{aligned}
$$

or after integrating and using Eq (7),

$$
U \doteq \frac{1}{2} \Sigma_{i j} A_{i j} F_{i} F_{j}=\frac{1}{2} \Sigma_{i} F_{i} D_{F i}
$$

A very important relationship can be obtained by differentiation of the strain energy $U$ with respect to a force, say $F_{1}$. Expansion of $E q(8)$ in terms containing $F_{1}$ first gives

$$
U=\frac{1}{2}\left(+A_{11} F_{1}^{2}+A_{12} F_{1} F_{2}+A_{21} F_{2} F_{1}+A_{13} \dot{F}_{1} F_{3}+A_{31} F_{3} \dot{F}_{1}\right)
$$

so that differentiation with respect to $F_{1}$ gives

$$
\frac{\partial \dot{U}}{\partial F_{1}}=\frac{1}{2}\left(+2 A_{11} F_{1}+A_{12} F_{2}+A_{21} \dot{F}_{2}+A_{13} F_{3}+A_{3 i} F_{3}\right) \text {. }
$$

Since $A_{i j}=A_{j i}$, according to the Reciprocal Theorem,

$$
\frac{\partial U}{\partial F_{1}}=A_{11} F_{1}+\dot{A}_{12} F_{2}+A_{13} F_{3}
$$

which, according to Eqs (1) or Eq. (7), is simply $D_{F i} ;$ thus,

$$
\mathrm{L}_{\mathrm{F}+1}=\frac{\mathrm{dU}}{\mathrm{dr}}
$$

This result is known as Castigliano's Theorem. The partial derivative of the strain e nergy of a linear elastic system with respect to a force equals the working deflection of that force. In general,

$$
D_{F i}=\frac{\partial U}{\partial F_{i}}
$$

\section{Structure Position}

The working deflection of a force acting on a structure is actually the total working deflection of all components of the force system acting on the structure: For example; consider the spring shown in Fig. 3. Suppose that while the left end moves through a distance $x_{1}$, the spring force increases from 0 to full value $\dot{F}_{1}$. If the spring constant is $K_{1}$, the total stretch of the spring $s_{1}$ is equal to $F_{1} / K_{1}$ and the total movement of the right end of the spring is $x_{1}+s_{1}$.

The work $W_{L}$ done by the left force is

$$
W_{L}=-\int_{0}^{F_{1}} F_{1}^{\prime} d x_{1}^{\prime}
$$




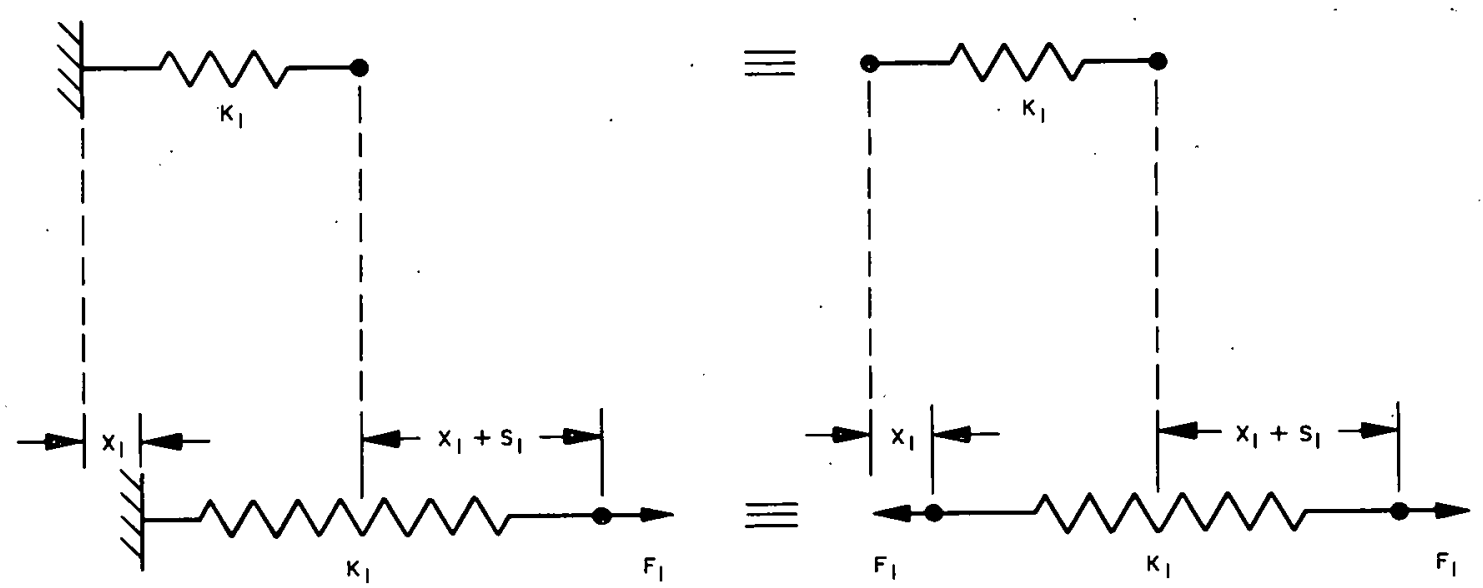

日. FINAL POSITION

Fig. 3 Changed Position of à Spring

and the work $\mathrm{W}_{\mathrm{R}}$ done by the right force is

$$
W_{R}=+\int_{0}^{F_{1}} F_{1}^{\prime} d\left(x_{1}^{\prime}+s_{1}^{\prime}\right)=+\int_{0}^{F_{1}} F_{1}^{\prime} d x_{1}^{\prime}+\int_{0}^{F_{1}} F_{1}^{\prime} d s_{1}^{\prime} .
$$

The strain energy $U$ in the spring is equal to the total work done on the structure. Thus,

$$
\begin{aligned}
U & =W_{L}+W_{R} \\
& =\left(-\int_{0}^{F_{1}} F_{1}^{\prime} \mathrm{dx}_{1}^{\prime}\right)+\left(+\int_{0}^{F_{1}} F_{1}^{\prime} \mathrm{dx}_{1}^{\prime}+\int_{0}^{F_{1}} F_{1}^{\prime} \mathrm{ds}_{1}^{\prime}\right) \\
& =\int_{0}^{F_{1}} \mathrm{~F}_{1}^{\prime} \mathrm{ds}_{1}^{\prime},
\end{aligned}
$$

which is independent of the final position of the spring. Since $s_{1}=F_{1} / K_{1}$, then

$$
\mathrm{U}=\int_{0}^{\mathrm{F}_{1}} \mathrm{~F}_{1}^{\prime} \mathrm{d}\left(\mathrm{F}_{1} / \mathrm{K}_{1}\right)=\left(\frac{1}{2 \mathrm{~K}_{1}}\right) \mathrm{F}_{1}^{2}
$$

Then, according to $\mathrm{Eq}(8)$, the deflection influence coefficient of $F_{1}$ is

$$
A_{11}=1 / K_{1}
$$

so that the working deflection of $F_{1}$ is, according to Eq (7),

$$
D_{F_{1}}=A_{11} F_{1}=\left(1 / \mathrm{K}_{1}\right) F_{1}=s_{1} \text {. }
$$

Thus, the working deflection of the force system: $F_{1}$ is simply the stretch of the spring, as is expected.

In general, working deflections of force systems acting on a linear elastic structure are indepenident of the final position of the structure and depend only on the final deformation of the structure. 


\section{Strain Energy}

\section{Beam Energy}

The influence coefficients for one system of forces can be determined from the influence coefficients of an equivalent system of forces by consideration of the strain energy in the structure. Calculations involved in this process will be carried out for a cantilever beam and a simple support beam in order to clarify the development of the necessary formulas.

The strain energy for a uniform beam under the usual engineering approximations (Ref 5) is

$$
\mathrm{U}=\int_{0}^{\mathrm{L}}\left[\left(\frac{\mathrm{l}}{2 \mathrm{EI}}\right) \mathrm{M}^{2}+\left(\frac{1}{2 \mathrm{E}_{\mathrm{s}} \mathrm{A}}\right) \mathrm{v}^{2}+\left(\frac{1}{2 \mathrm{EA}}\right) \mathrm{F}^{2}\right] \mathrm{dx}
$$

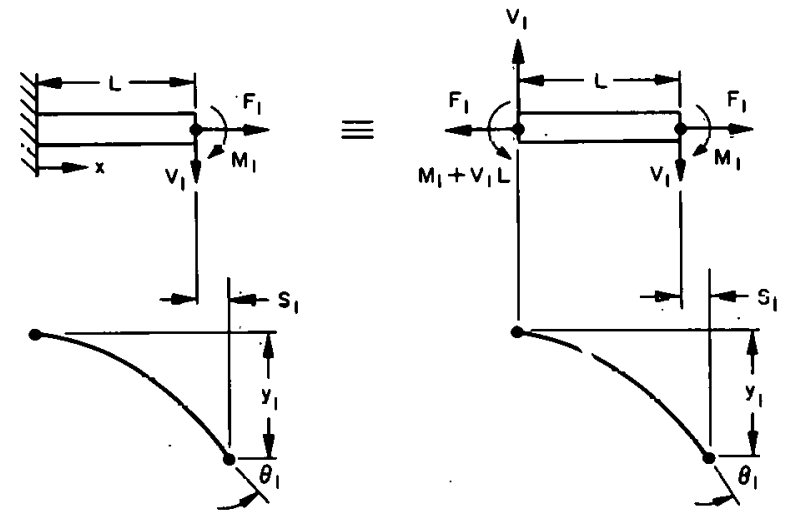

Fig. 4 Cantilever Beam where

$\mathrm{L} \quad=$ length of a beam, in.

$\mathrm{x} \quad=$ distance along beam, in.

$\mathrm{E} \quad=$ tensile modulus of elasticity, $1 \mathrm{~b}-\mathrm{in} .{ }^{-2}$

$E_{S}=$ shear modulus of elasticity, lb-in. -2

EI = bending stiffness of beam, lb-in. ${ }^{2}$

$E_{S} A_{s}=$ shear stiffness of beam, lb

$\mathrm{EA} \quad=$ tensile stiffness of beam, lb

$\mathrm{M} \quad=$ bending moment at $\mathrm{x}$, in. $-1 \mathrm{~b}$

$\mathrm{V} \quad=$ shear force at $\mathrm{x}, \mathrm{lb}$

$F \quad=$ tensile force $a t x, l b$

Bending in one plane, shear in the same plane, and tension are the only deformations considered in Eq (10).

\section{Cantilever Beam}

Consider a cantilever beam loaded with force systems $F_{1}, V_{1}$, and $M_{1}$ as shown in Fig. 4. The load distribution along this beam is then

$$
\begin{aligned}
& M=M_{1}+V_{1}(L-x), \\
& V=V_{1},
\end{aligned}
$$

and

$$
F=F_{1} \text {. }
$$

Substitution of these relations into the beam energy equation gives

$$
U=\int_{U}^{L}\left\{\left(\frac{1}{2 E I}\right)\left[M_{1}+v_{1}(L-x)\right]^{2}+\left(\frac{1}{2 E_{s} A_{S}}\right) v_{1}^{2}+\left(\frac{1}{2 E A}\right) F_{1}^{2}\right\} d x
$$

whlch, after lntcgration, becoines

$$
U=M_{1}^{2}\left(\frac{L}{2 E I}\right)+M_{1} v_{1}\left(\frac{L^{2}}{2 E I}\right)+v_{1}^{2}\left(\frac{L^{3}}{6 E I}+\frac{L}{2 E_{s} A_{s}}\right)+F_{1}^{2}\left(\frac{L}{2 E A}\right)
$$

The cantilever orientation consists of having the left end of the beam on and tangent to the reference line from which deflections are measured. With this orientation, the force components at the left end undergo no deflection and do no work. 
The working deflection of the force system $\mathrm{M}_{1}$ in Fig. 4 is simply the slope $\theta_{1}$ at the right end; the working deflection of the force system $v_{1}$ is the deflection $y_{1}$ at the right end; and the working deflection of the force system $F_{1}$ is the elongation $s_{1}$ of the beam. Therefore, application of Castigliano's Theorem, Eq (9), to the cantilever beam energy, Eq (12), gives

$$
\begin{aligned}
& \theta_{1}=D_{M_{1}}=\frac{\partial U}{\partial M_{1}}=\left(\frac{L}{E I}\right) M_{1}+\left(\frac{L^{2}}{2 E I}\right) V_{1}, \\
& y_{1}=D_{V 1}=\frac{\partial U}{\partial V_{1}}=\left(\frac{L^{2}}{2 E I}\right) M_{1}+\left(\frac{L^{3}}{3 E I}+\frac{L}{E_{s} A_{s}}\right) V_{1},
\end{aligned}
$$

and

$$
s_{1}=D_{F l}=\frac{\partial U}{\partial F_{1}}=\left(\frac{L}{E A}\right) F_{1} \text {. }
$$

\section{Simple Support Beam}

Next, consider a simple support beam loaded with force systems $F_{a}, M_{b}, M_{c}$ as shown in Fig. 5. The load distribution along the beam is

$$
\begin{aligned}
& \mathrm{M}=\left(1-\frac{\mathrm{x}}{\mathrm{L}}\right) \mathrm{M}_{\mathrm{b}}+\left(\frac{\mathrm{x}}{\mathrm{L}}\right) \mathrm{M}_{\mathrm{c}}, \\
& \mathrm{V}=(1 / \mathrm{L})\left(\mathrm{M}_{\mathrm{b}}-\mathrm{M}_{\mathrm{c}}\right),
\end{aligned}
$$

and

$$
F=F_{a}
$$

The simple support orientation consists of having the ends of the beam on the reference line from which deilections are measured. With this orientation, the shear loads at each end undergo no deflection and do no work. Thus, the working deflection of the force system $M_{c}$ is the slope $\theta_{c}$ at the right end, the working deflection of the force system $M_{b}$ is the slope $\theta_{b}$ at the left end, and the working deflection of the force system $F_{a}$ is the elongation $s_{a}$ of the beam.

Instead of evaluating the energy integral and then differentiating, the process can be reversed in calculating working deflections by Castigliano's Theorem. Thus, from Eq (9) and Eq (10),

$$
\begin{array}{r}
s_{a}=D_{F a}=\frac{\partial U}{\partial F_{a}}=\int_{0}^{L}\left[\left(\frac{1}{E l}\right)(M)\left(\frac{\partial M}{\partial F_{a}}\right)+\left(\frac{1}{E_{s} A_{s}}\right)(V)\left(\frac{\partial V}{\partial F_{a}}\right)\right. \\
\left.+\left(\frac{1}{E A}\right)(F)\left(\frac{\partial F}{\partial F_{a}}\right)\right] d x .
\end{array}
$$

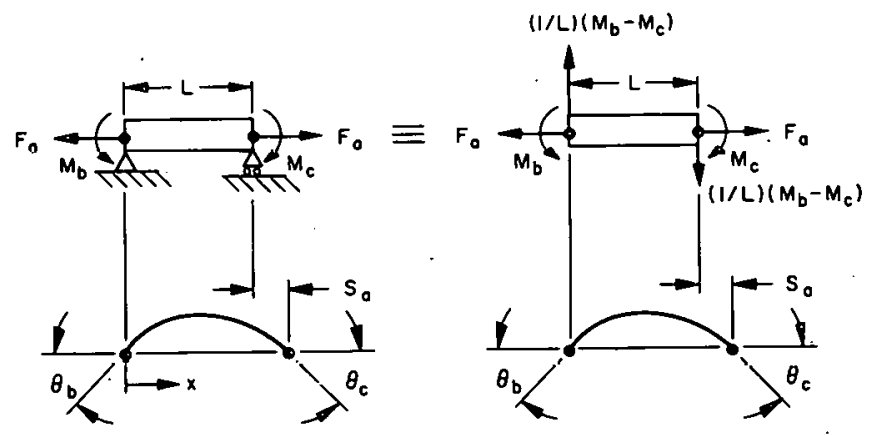

Fig. 5 Simple Support Beam 
From Eq (14),

$$
\frac{\partial M}{\partial F_{a}}=0, \frac{\partial V}{\partial F_{a}}=0, \text { and } \frac{\partial F}{\partial F_{a}}=1 \text {, }
$$

so that

$$
s_{a}=\int_{0}^{L}\left[0+0+\left(\frac{1}{E A}\right)\left(F_{a}\right)(1)\right] d x=\left(\frac{L}{E A}\right) F_{a}
$$

Similarly,

$$
\begin{aligned}
\theta_{b}= & D_{M b}=\frac{\partial U}{\partial M_{b}}=\int_{0}^{L}\left[\left(\frac{1}{E I}\right)(M)\left(\frac{\partial M}{\partial M_{b}}\right)+\left(\frac{1}{E_{s} A_{s}}\right)(V)\left(\frac{\partial V}{\partial M_{b}}\right)+\left(\frac{1}{E A}\right)(F)\left(\frac{\partial F}{\partial M_{b}}\right)\right] d x \\
= & \int_{0}^{L}\left\{\left(\frac{1}{E I}\right)\left[M_{b}\left(1-\frac{x}{L}\right)+M_{c}\left(\frac{x}{L}\right)\right]\left(1-\frac{x}{L}\right)\right. \\
& \left.\quad+\left(\frac{1}{E_{k} A_{k}}\right)\left[\left(\frac{1}{I}\right)\left(M_{h}-M_{r !}\right)\right]\left(\frac{1}{T}\right)+\left(\frac{1}{F \cdot A}\right)\left(F_{A}\right)(0)\right\} d x \\
= & \left(\frac{L}{3 E I}+\frac{1}{E_{s} A_{s} L}\right) M_{b}+\left(\frac{L}{6 E I}-\frac{1}{E_{s} A_{s} L}\right) M_{c},
\end{aligned}
$$

and $\theta_{c}$ is found the same way. The three working deflections thus evaluated are

$$
\begin{aligned}
& s_{a}=\left(\frac{L}{E A}\right) F_{a}, \\
& \theta_{b}=\left(\frac{L}{3 E I}+\frac{1}{E_{s} A_{s} L}\right) M_{b}+\left(\frac{L}{6 E I}-\frac{1}{E_{s} A_{s} L}\right) M_{c},
\end{aligned}
$$

and

$$
\theta_{c}=\left(\frac{L}{6 E I}-\frac{1}{E_{s}^{*} A_{s} L}\right) M_{b}+\left(\frac{L}{3 E I}+\frac{l}{E_{s} A_{s} L}\right) M_{c} \text {. }
$$

\section{Transformation from Cantilever to Simple Support}

By comparison of Figs. 4 and 5, the cantilever beam and the single support beam are seen to have the same loading distributions if

$$
\begin{aligned}
& M_{1}=M_{c} \\
& V_{1}=(1 / L)\left(M_{b}-M_{c}\right),
\end{aligned}
$$

and

$$
F_{1}=F_{a} \text {. }
$$

Then, the cantilever deflections can be found in terms of the simple support loads by putting the loads of Eqs (16) in the cantilever deflections of Eqs (13). After simplification, the equations her.nme.

$$
\begin{aligned}
& \theta_{1}=\left(\frac{L}{2 E I}\right) M_{b}+\left(\frac{L}{2 E I}\right) M_{C}, \\
& y_{1}=\left(\frac{L^{2}}{3 E I}+\frac{1}{E_{E} A_{E}}\right) M_{b}+\left(\frac{L^{2}}{6 E I}-\frac{1}{E_{B} A_{3}}\right) M_{c},
\end{aligned}
$$

and

$$
s_{1}=\left(\frac{L}{E A}\right) F_{a} \text {. }
$$


Then, substitution of deflections from Eqs (17) and forces from Eqs (16) into the energy equation (8) gives

or

$$
\begin{aligned}
U & =\frac{1}{2}\left(M_{1} \theta_{1}+V_{1} y_{l}+F_{l} s_{1}\right)=\frac{1}{2}\left\{\left(M_{c}\right)\left[\left(\frac{L}{2 E I}\right) M_{b}+\left(\frac{L}{2 E I}\right) M_{c}\right]\right. \\
& \left.+(1 / L)\left(M_{b}-M_{c}\right)\left[\left(\frac{L^{2}}{3 E I}+\frac{1}{E_{s} A_{s}}\right) M_{b}+\left(\frac{L^{2}}{6 E I}-\frac{1}{E_{s} A_{s}}\right) M_{c}\right]+\left(F_{a}\right)\left[\left(\frac{L}{E A}\right) F_{a}\right]\right\}
\end{aligned}
$$

$$
\begin{aligned}
U=\left(\frac{L}{2 E A}\right) F_{a}^{2}+\left(\frac{L}{6 E I}+\frac{1}{2 E_{s} A_{s} L}\right) M_{b}^{2} & +\left(\frac{L}{6 E I}-\frac{1}{E_{s}^{A} L}\right) \\
& +\left(\frac{L}{6 E I}+\frac{1}{2 E_{s} A_{s} L}\right) M_{c}^{2}
\end{aligned}
$$

Differentiation with respect to the force systems gives

$$
\begin{aligned}
& D_{F_{a}}=\frac{\partial U}{\partial F_{a}}=\left(\frac{L}{E A}\right) F_{a}, \\
& D_{M_{b}}=\frac{\partial U}{\partial M_{b}}=\left(\frac{L}{3 E I}+\frac{1}{E_{s} A_{s} L}\right) M_{b}+\left(\frac{1}{6 E I}-\frac{1}{E_{s} A_{s} L}\right) M_{c},
\end{aligned}
$$

and

$$
\mathrm{D}_{M_{c}}=\frac{\partial U}{\partial M_{\dot{c}}}=\left(\frac{L}{6 E I}-\frac{l}{E_{s} A_{s} L}\right) M_{b}+\left(\frac{L}{3 E I}+\frac{l}{E_{s} A_{s} L}\right) M_{c} \text {, }
$$

which are the same as in Eqs (15). Thus, by using the cantilever deflection formulas of Eqs (13) and the force relationships of Eqs (16) in an energy equation, the working deflections of the simple support beam have been obtained.

This transformation from the influence coefficients of the cantilever force system to the influence coefficients of the simple support force system shows that the cantilever and simple support beams are really the same structure with the same loading. The only real difference is the change of the reference line from which deflections are measured, as shown in Fig. 6, to correspond with the change in force system notation.

According to Eqs $(17 \mathrm{c})$ and $(19 a), s_{1}=s_{a}$. This is true in Fig. 6 if deflections are small compared to structure dimensions so that $L>>s_{1}$, and if slopes are small so that $\sin \theta \cong \theta$ and $\cos \theta \cong 1$, where $\theta=\theta_{1}, \theta_{a}$, or $\theta_{b}$. As shown.in Fig. 6,
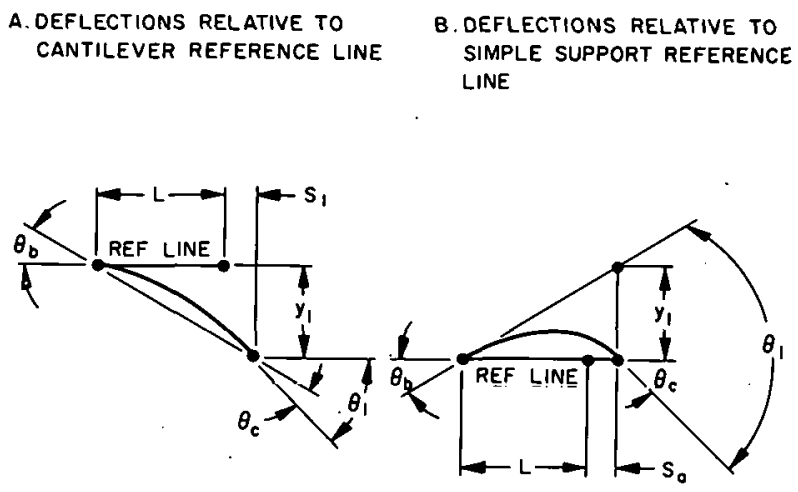

$$
\begin{gathered}
\text { Fig. } 6 \text { Equivalence of Cantilever and } \\
\text { Simple Support Beam }
\end{gathered}
$$


and

$$
\theta_{b}=(1 / L) y_{1}
$$

$$
\theta_{c}=\theta_{1}-(1 / L) y_{1}
$$

Substitution of the values from Eqs (17) into these equations gives

$$
\theta_{b}=\left(\frac{L}{3 E I}+\frac{1}{E_{s}{ }^{A} L}\right) M_{b}+\left(\frac{L}{6 E I}-\frac{1}{E_{s} A_{s} L}\right) M_{c} \text {, }
$$

and

$$
\begin{aligned}
\theta_{c} & =\left[\left(\frac{L}{2 E I}\right) M_{b}+\left(\frac{L}{2 E I}\right) M_{c}\right]-\left[\left(\frac{L}{3 E I}+\frac{l}{E_{s} A_{s} L}\right) M_{b}+\left(\frac{L}{6 E I}-\frac{1}{E_{s} A_{s} L}\right) M_{c}\right. \\
& =\left(\frac{L}{6 E I}-\frac{1}{E_{s} A_{s} L}\right) M_{b}+\left(\frac{L}{3 E I}+\frac{1}{E_{s} A_{s} L}\right) M_{c},
\end{aligned}
$$

which are the same as obtained in Eqs (15). Thus, the use of strain energy in transforming influence coefficients from one force system to another equivalent force system is checked by direct use of geometry:

III. SYSTEMATIC CALCULATION

\section{A. Cantilever}

\section{Influence Coefficients}

In order to keep calculations involving many variables in simultaneous equations under control, a systematic procedure involving matrices* will be used. Consider the cantilever deflections of Eqs (13) rewritten with all influence coefficients present:

$$
\begin{aligned}
& \theta_{1}=\left(\frac{L}{E I}\right) M_{1}+\left(\frac{L^{2}}{2 E I}\right) v_{1}+(0) F_{1} \\
& y_{1}=\left(\frac{L^{2}}{2 E I}\right) M_{1}+\left(\frac{L^{3}}{3 E I}+\frac{L}{E_{s} A_{s}}\right) v_{1}+(0) F_{1} \\
& s_{1}=(0) M_{1}+(0) v_{1}+\left(\frac{L}{E A}\right) F_{1}
\end{aligned}
$$

In matrix form, thesc equations becine

\begin{tabular}{|l|l|l|c|}
\hline$\theta_{1}$ & $\frac{\mathrm{L}}{\mathrm{EI}}$ & $\frac{\mathrm{L}^{2}}{2 \mathrm{EI}}$ & 0 \\
\hline $\mathrm{y}_{1}=$ & $\frac{\mathrm{L}^{2}}{2 \mathrm{EI}}$ & $\frac{\mathrm{L}^{3}}{3 \mathrm{EI}}+\frac{\mathrm{L}}{\mathrm{E}_{\mathrm{S}} \mathrm{A}_{\mathrm{S}}}$ & 0 \\
\hline $\mathrm{s}_{1}$ & $\mathbf{0}$ & $\mathrm{V}_{1}$ \\
\hline 0 & 0 & $\frac{\mathrm{L}}{\mathrm{EA}}$ \\
\hline
\end{tabular}

or aimply

$$
\left(D_{p}\right)=\left(A_{p}\right) \times(P)
$$

where

$(P)=$\begin{tabular}{c|}
$M_{1}$ \\
\hline$V_{1}$ \\
\hline$F_{1}$ \\
\hline
\end{tabular}

* Elementary properties of matrices are discussed in Ref 6 . 


$$
\begin{aligned}
& \left(D_{p}\right)=\begin{array}{|c|}
\theta_{1} \\
\hline y_{1} \\
\hline s_{1} \\
\hline
\end{array} \\
& \left(A_{p}\right)=\begin{array}{|l|l|l|}
\hline \frac{L}{E I} & \frac{L^{2}}{2 E I} & 0 \\
\hline \frac{L^{2}}{2 E I} & \frac{L^{3}}{3 E I}+\frac{L}{E_{s}{ }^{A}} & 0 \\
\hline 0 & 0 & \frac{L}{E A} \\
\hline
\end{array}
\end{aligned}
$$

Let $\left(D_{p}\right)_{i j}=$ element in row $i$ and column $j$ of matrix $\left(D_{p}\right)$. The equations are so arranged that $\left(D_{p}\right)_{i l}$ is the working deflection of force $(P)_{i l}$ for $i=1,2$, and 3 . With this arrangement, the flexibility matrix $\left(A_{p}\right)$ is symmetrical, as required by Eq (6).

Energy

According to Eq (8), the cantilever energy is

$$
U=\frac{1}{2}\left(M_{1} \theta_{1}+V_{1} y_{1}+F_{1} s_{1}\right) ;
$$

or in matrix form,

$$
(U)=\frac{1}{2} \times\left(P^{T}\right) \times\left(D_{p}\right)
$$

where $(U)=U$ the energy matrix of 1 row and 1 column, and $\left(P^{T}\right)$ is the transpose of $(P)$.

Substitution of the cantilever deflection matrix $\left(D_{p}\right)$ from Eq (20) into Eq (2la) gives

$$
U=\frac{1}{2} \times\left(P^{T}\right) \times\left(A_{p}\right) \times(P)
$$

Equations (2la) and (2lb) are matrix equivalents of Eq (8)

B. Simple Support

\section{CTAC Rule}

The cantilever matrix deflection equation (20) and the energy equation (2lb) can be used to determine the matrix deflection equations for the simple support beam, once the relationship between the force systems is put in matrix form. Equation (16) is equivalent to:

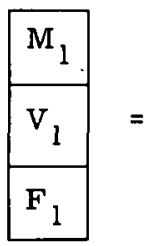

\begin{tabular}{|c|c|c|}
\hline 0 & 0 & 1 \\
\hline 0 & $\frac{1}{L}$ & $-\frac{1}{L}$ \\
\hline 1 & 0 & 0 \\
\hline
\end{tabular}

\begin{tabular}{|c|}
\hline $\mathbf{F}$ \\
\hline$M_{b}$ \\
\hline$M_{c}$ \\
\hline
\end{tabular}

or

$$
(P)=(C) \times(Q) \text {, }
$$

where

$(Q)=$\begin{tabular}{|l|}
\hline$F_{a}$ \\
\hline$M_{b}$ \\
\hline$M_{c}$ \\
\hline
\end{tabular} 
and

$(C)=$\begin{tabular}{|c|c|c|}
\hline 0 & 0 & 1 \\
\hline 0 & $\frac{1}{L}$ & $-\frac{1}{L}$ \\
\hline 1 & 0 & 0 \\
\hline
\end{tabular}

$=$ connection matrix relating cantilever forces (P) to simple support forces (Q).

Substituting Eq (22) into Eq (2la) gives

$$
(U)=\frac{1}{2} \times[(C) \times(Q)]^{T} \times\left(D_{p}^{\prime} ;\right.
$$

or, since the transposed product of two matrices is the product of the transposes of the two matrices in reverse order,

$$
(\mathrm{U})=\frac{1}{2} \times\left(\mathrm{Q}^{\mathrm{T}}\right) \times\left(\mathrm{C}^{\mathrm{T}}\right) \times\left(\mathrm{D}_{\mathrm{p}}\right)
$$

I_et

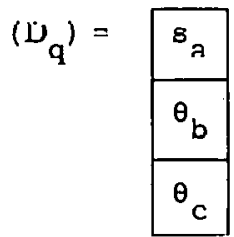

= simple support deflection malrix corresponding to the simple support force matrix (Q),

so that, as in Eq (2la),

$$
(U)=\frac{l}{2}\left(Q^{T}\right) \times\left(D_{q}\right)
$$

Comparison of this matrix equation with Eq (23) shows that

$$
\left(D_{q}\right)=\left(C^{T}\right) \times\left(D_{p}\right)
$$

Next, substitution of $\left(D_{p}\right)$ from $E q(20)$ gives

$$
\left(D_{y}\right)=\left(C^{T}\right) \times\left(A_{p}\right) \times(P) .
$$

and substitution of (P) from Eq (22) gives

$$
\left(D_{q}\right)=\left(C^{T}\right) \times\left(A_{p}\right) \times(C) \times(Q)
$$

Let $\left(A_{Q}\right)$ be the simple support flexibility matrix relating $\left(D_{\Omega}\right)$ and $(Q)$ in the equation

$$
\left(D_{q}\right)=\left(A_{Q}\right) \times(Q)
$$

Then, from Eqs (24b) and (24 $c$ ).

$$
\left(A_{q}\right)=\left(C^{T}\right) \times\left(A_{p}\right) \times(C)
$$

'I'his is the most important equation of all-the "CTAC" equation. It gives the flexibility of a system of forces acting on a linear-elastic structure in terms of (1) the flexibility of an equivalent second system of forces and (2) the connection matrix relating the second system to the first.

In more simple notation, let $\mathrm{A}$ be the flexibility matrix of a force matrix $\mathrm{P}$, and $\mathrm{C}$ be the correction matrix relating $P$ to an equivalent force matrix $P^{\prime}$. Then, the flexibility matrix $A^{\prime}$ of $P^{\prime}$ is simply

$$
A^{\prime}=C^{T} A C \text {, }
$$

where $P=C P^{\prime}$. 
As a check, the CTAC equation (Eq 25) will be evaluated for the simple support beam. Thus,

\begin{tabular}{|c|c|c|c|c|c|c|c|c|c|c|c|}
\hline \multirow{3}{*}{$\left(A_{q}\right)=$} & 0 & 0 & 1 & \multirow[t]{3}{*}{$\mathbf{x}$} & $\frac{\mathrm{L}}{\mathrm{EI}}$ & $\frac{\mathrm{L}^{2}}{2 \mathrm{EI}}$ & 0 & \multirow[t]{3}{*}{$\mathbf{x}$} & 0 & 0 & 1 \\
\hline & 0 & $\frac{1}{L}$ & 0 & & $\frac{L^{2}}{2 E I}$ & $\frac{L^{3}}{3 E I}+\frac{L}{E_{S} A_{S}}$ & 0 & & 0 & $\frac{1}{\mathrm{~L}}$ & $\frac{1}{\mathrm{~L}}$ \\
\hline & 1 & $-\frac{1}{L}$ & 0 & & 0 & 0 & $\frac{\mathrm{L}}{\mathrm{EA}}$ & & 1 & 0 & 0 \\
\hline \multirow[t]{3}{*}{$=$} & $\frac{L}{E A}$ & & 0 & & & 0 & & & & & \\
\hline & 0 & $\frac{\mathrm{L}}{3 \mathrm{EI}}$ & & & $\frac{\mathrm{L}}{6 \mathrm{EI}}$ & $\frac{1}{E_{s}{ }^{A}{ }^{L}}$ & & & & & \\
\hline & 0 & $\frac{\mathrm{L}}{6 \mathrm{EI}}$ & & & $\frac{L}{3 E I}$ & $\frac{l}{E_{s} A_{s}^{L}}$ & & & & & \\
\hline
\end{tabular}

Substitution into Eq (24c) gives

\begin{tabular}{|c|c|c|c|}
\hline$s_{a}$ & $\frac{L}{E A}$ & 0 \\
\hline$\theta_{b}=$ & $\frac{L}{3 E I}+\frac{1}{E_{s} A_{s} L}$ & $\frac{L}{6 E I}-\frac{1}{E_{s} A_{s} L}$ \\
\hline$\theta_{c}$ & $\times$ & $F_{b}$ \\
\hline 0 & $\frac{L}{6 E I}-\frac{1}{E_{s} A_{s} L}$ & $\frac{L}{3 E I}+\frac{1}{E_{s} A_{s} L}$ \\
\hline
\end{tabular}

This is equivalent to the three simultaneous equations

$$
\begin{aligned}
& s_{a}=\left(\frac{L}{E A}\right) F_{a}+(0) M_{b}+(0) M_{c}, \\
& \theta_{b}=(0) F_{a}+\left(\frac{L}{3 E I}+\frac{1}{E_{s} A_{s} L}\right) M_{b}+\left(\frac{L}{6 E I}-\frac{1}{E_{s} A_{s} L}\right) M_{c},
\end{aligned}
$$

and

$$
\theta_{c}=(0) F_{a}+\left(\frac{L}{6 E I}-\frac{1}{E_{s} A_{s} L}\right) M_{b}+\left(\frac{L}{3 E I}+\frac{1}{E_{s} A L}\right) M_{c}
$$

which check Eq (15). Thus, the CTAC procedure does lead to the correct result.

IV. APPLICATION OF CTAC

A. Structure in WAPD-115.

\section{Given Data}

The problem is to determine the influence coefficients and modes of vibration of the structure used as an example in WAPD-115 (Ref 7$)$ and shown in Fig. 7. Geometric and flexibility coefficients are given in the following table. 
TABLE OF GEOMETRIC AND FLEXIBILITY COEFFICIENTS

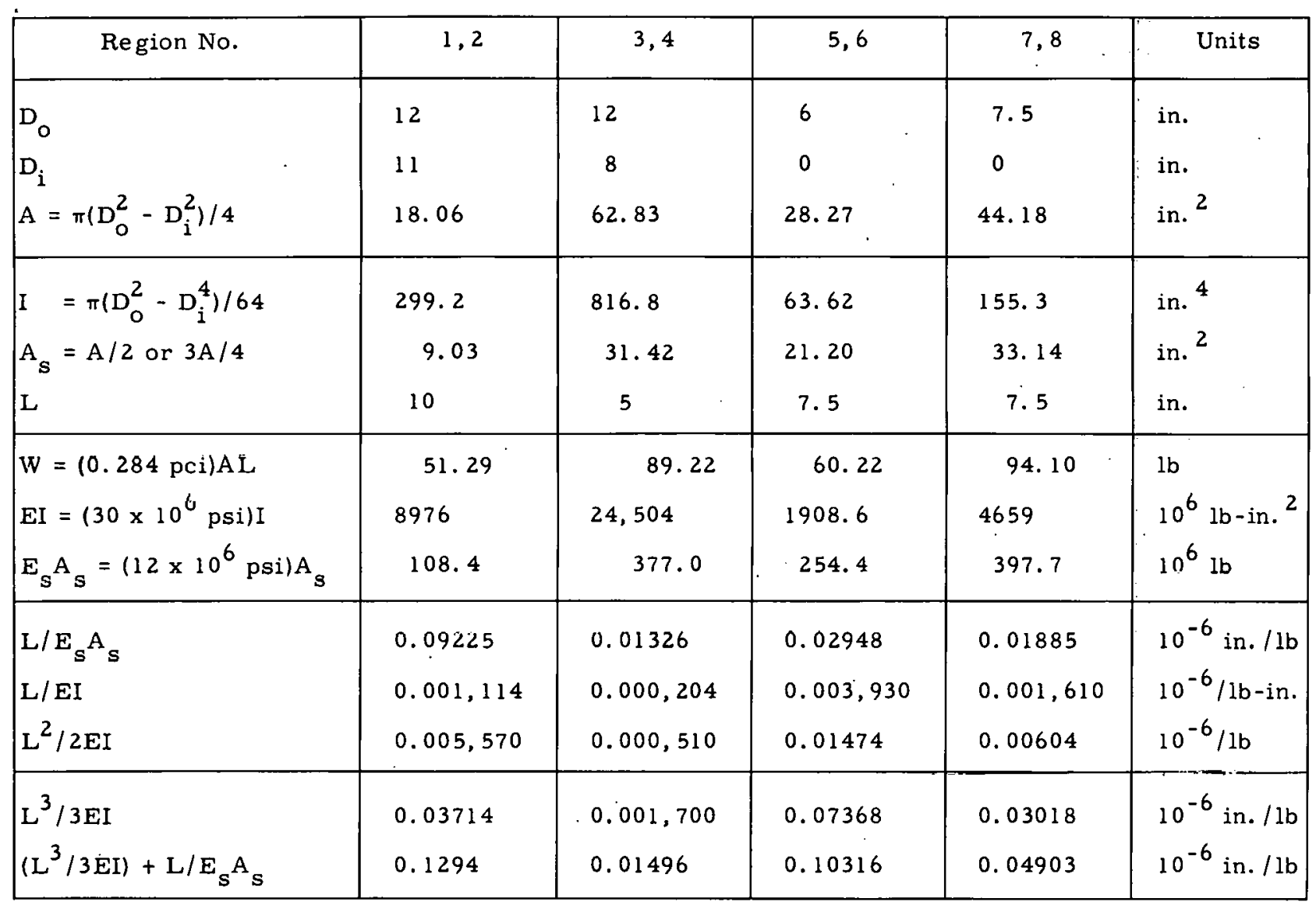
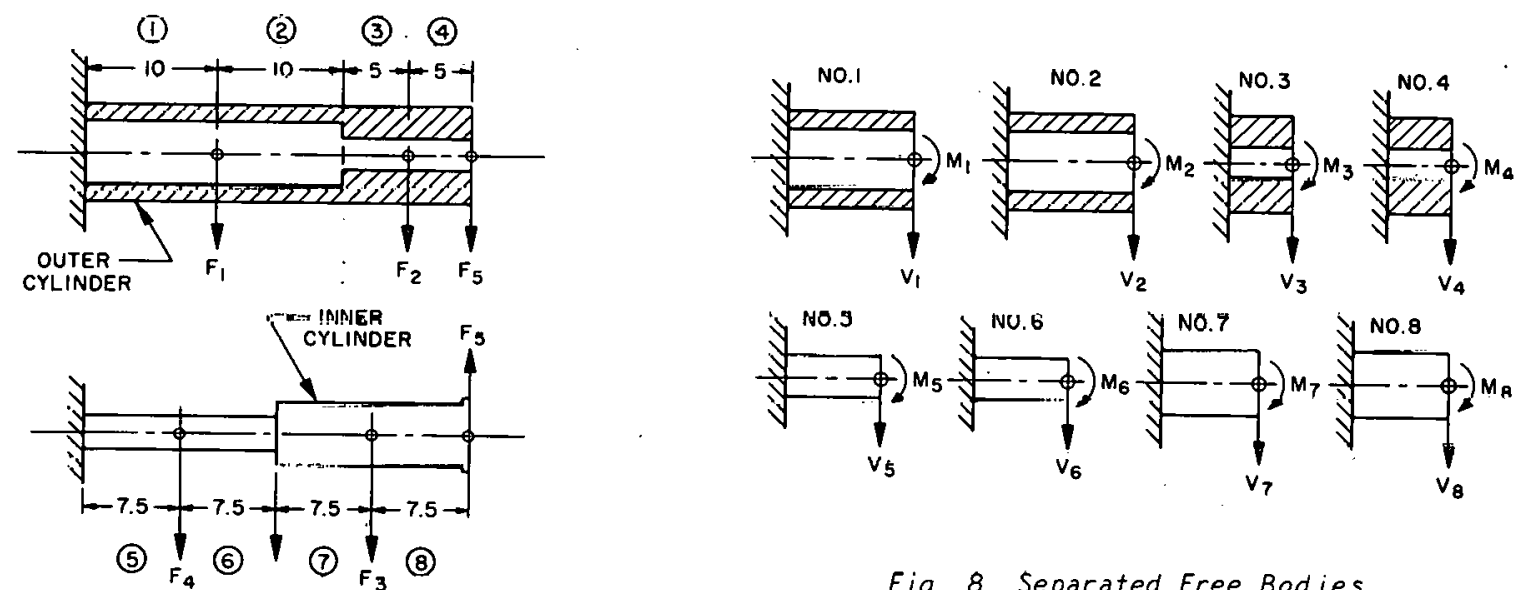

Fig. 8 Separated Free Bodies

Fig. 7 Geometry of Sample

Problem 
The loads, including the statically indeterminate end reaction $F_{5}$ between the two cylinders, may be put into the single. force matrix:

\begin{tabular}{|l|}
$(F)=F_{1}$ \\
\hline$F_{2}$ \\
\hline$F_{3}$ \\
\hline$F_{4}$ \\
\hline$F_{5}$ \\
\hline
\end{tabular}

\section{Flexibility of a Subdivided Free Body}

Consider region No. 1 as a separate free body with cantilever loads $V_{1}$ and $M_{1}$ as shown in Fig. 8. These loads can be put into the force matrix:

$$
\left(P_{1}\right)=\mathrm{M}_{1}
$$

The cantilever equations for region No. 1 are

$$
D_{M_{1}}=\left(\frac{L}{E I}\right)_{1} M_{1}+\left(\frac{L^{2}}{2 \mathrm{EI}}\right)_{1} V_{1}=\left(1.114 \times 10^{-9} / \text { in. }-1 b\right) M_{1}+\left(5.57 \times 10^{-9} / \overline{l b}\right) V_{1}
$$

and

$$
D_{V_{1}}=\left(\frac{L^{2}}{2 E I}\right)_{1} M_{1}+\left(\frac{L^{3}}{3 E I}+\frac{L}{E_{S} A_{S}}\right)_{1} V_{1}=\left(5.57 \times 10^{-9} / 1 b\right) M_{1}+\left(129.4 \times 10^{-9} \text { in. } / 1 b\right) V_{1}
$$

so that the flexibility matrix for $\left(P_{1}\right)$ on body No. 1 is

$$
\left(A_{1}\right)=\begin{array}{|c|c|}
\hline 1.114 \mathrm{in.}^{-1} & 5.57 \\
\hline 5.57 & 129.4 \mathrm{in} . \\
\hline
\end{array}
$$

By inspection of Figs. 7 and 8 , the moment at the right end of body No. 1 is seen to be

$$
M_{1}=(15 \text { in. }) F_{2}+(20 \text { in. }) F_{5} \text {, }
$$

and the shear load on body INo. 1 is

$$
v_{1}=F_{1}+F_{2}+F_{3}
$$

In expanded form, the equations become

$$
M_{1}=(0) F_{1}+(15 \text { in. }) F_{2}+(0) F_{3}+(0) F_{4}+(20 \text { in. }) F_{5}
$$

and

$$
V_{1}=(1) F_{1}+(1) F_{2}+(0) F_{3}+(0) F_{4}+(1) F_{5}
$$


so that

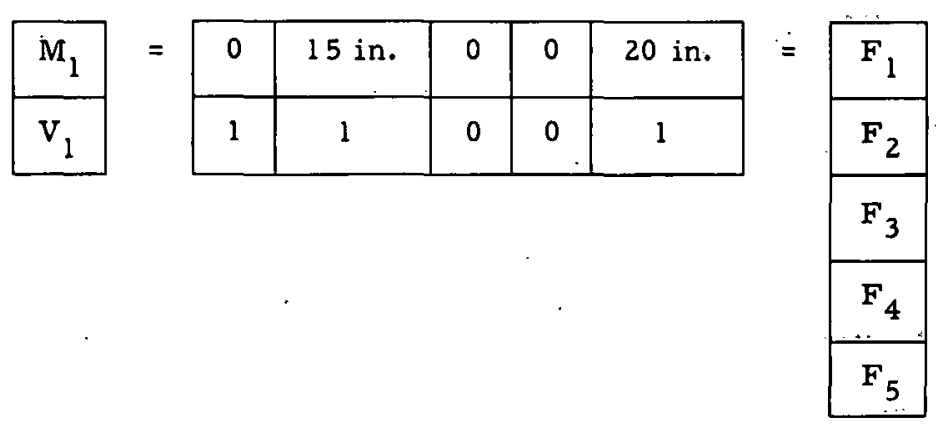

or

$$
\left(P_{1}\right)=\left(C_{1}\right) \times(F)
$$

where $\left(C_{1}\right)=$\begin{tabular}{|c|c|c|c|c|}
\hline 0 & 15 in. & 0 & 0 & 20 in. \\
\hline 1 & 1 & 0 & 0 & 1 \\
\hline
\end{tabular}

The flexibility matrix of (F) produced by deflections of body No. 1 is then, by the CTAC rule,

$$
\left(A_{F 1}\right)=\left(C_{1}^{T}\right) \times\left(A_{1}\right) \times\left(C_{1}\right)
$$

\begin{tabular}{|c|c|}
\hline 0 & 1 \\
\hline 15 in. & 1 \\
\hline$U$ & 0 \\
\hline 0 & 0 \\
\hline 20 in. & 1 \\
\hline
\end{tabular}

\begin{tabular}{|l|l|}
\hline $1.14 \mathrm{in.}^{-1}$ & 5.57 \\
\hline 5.57 & $129.4 \mathrm{in}$. \\
\hline
\end{tabular}

$\overline{\mathbf{x}}$

\begin{tabular}{|c|c|c|c|c|}
\hline$U$ & I b 2n. & $U$ & $U$ & LU In. \\
\hline 1 & 1 & 0 & 0 & 1 \\
\hline
\end{tabular}

$=$

\begin{tabular}{|c|c|c|c|c|}
\hline$\dot{U} .1 \angle Y 4$ & $\dot{U} . \angle 1 \angle Y \zeta$ & $\dot{U}$ & $u$ & $0 . \angle 4 U 8$ \\
\hline 0.21295 & 0.54715 & $u$ & 0 & 0.65855 \\
\hline 0 & 0 & 0 & 0 & 0 \\
\hline 0 & 0 & 0 & 0 & 0 \\
\hline 0.2408 & 0.65855 & 0 & 0 & 0.7978 \\
\hline
\end{tabular}

This is the flexibility matrix giving the deflections of the forces in (F) resulting from the flexibility of body No. 1 .

\section{Total Flexibility}

In the same way, the deflections due to body No. 2 can be determined. As before, let

$$
\left(P_{2}\right)=\begin{aligned}
& M_{2} \\
& \hline V_{2}
\end{aligned}
$$


so that

$$
\left(A_{2}\right)=\left(A_{1}\right)=\begin{array}{|l|c|}
\hline 1.114 \text { in. }^{-1} & 5.57 \\
\hline 5.57 & 129.4 \cdot \text { in. } \\
\hline
\end{array}
$$

The connection equations for $\left(P_{2}\right)$ in terms of $(F)$ are

and

$$
M_{2}=(5 \text { in. }) F_{2}+(10 \text { in. }) F_{5}
$$$$
\mathrm{V}_{2}=\mathrm{F}_{2}+\mathrm{F}_{5} \text {, }
$$

\begin{tabular}{|c|c|c|c|c|c|}
\hline \multirow[t]{2}{*}{$\left(C_{2}\right)=$} & 0 & 5 in. & 0 & 0 & $10 \mathrm{in.}$ \\
\hline & 0 & 1 & 0 & 0 & 1 \\
\hline
\end{tabular}

so that

Carrying through the multiplications of

$$
\left(A_{F 2}\right)=\left(C_{2}^{T}\right) \times\left(A_{2}\right) \times\left(C_{2}\right)
$$

gives

$\left(A_{F 2}\right)=$\begin{tabular}{|c|c|c|c|c|}
\hline 0 & 0 & 0 & 0 & 0 \\
\hline 0 & 0.21295 & 0 & 0 & 0.26865 \\
\hline 0 & 0 & 0 & 0 & 0 \\
\hline 0 & 0 & 0 & 0 & 0 \\
\hline 0 & 0.26865 & 0 & 0 & 0.3522 \\
\hline
\end{tabular}

The total flexibility of (F) due to both body No. 1 and body No. 2 is

$$
\left(A_{F 1,2}\right)=\left(A_{F 1}\right)+\left(A_{F 2}\right)
$$

\begin{tabular}{|c|c|c|c|c|}
\hline 0.1295 & 0.21295 & 0 & 0 & 0.2408 \\
\hline 0.21295 & 0.7601 & 0 & 0 & 0.9272 \\
\hline 0 & 0 & 0 & 0 & 0 \\
\hline 0 & 0 & 0 & 0 & 0 \\
\hline 0.2408 & 0.9272 & 0 & 0 & 1.15 \\
\hline
\end{tabular}

The final flexibility matrix for all eight primitives (basic beam structures) is found to be

$\begin{aligned}\left(A_{F}\right) & =\left(A_{F 1} \text { to } 8\right) \\ & =\begin{array}{|c|c|c|c|c|}\hline 0.1295 & 0.21295 & 0 & 0 & 0.2408 \\ \hline 0.21295 & 0.77506 & 0 & 0 & 0.94471 \\ \hline 0 & 0 & 2.0239625 & 0.32426 & -2.95355 \\ \hline 0 & 0 & 0.32426 & 0.10316 & -0.43481 \\ \hline 0.2408 & 0.94471 & -2.95355 & -0.43481 & 5.654975 \\ \hline\end{array}\end{aligned}$

$\times 10^{-6}$ in. $/ 1 \mathrm{~b}$

It is to be noted that all of the flexibility matrices are symmetrical, in agreement with the Reciprocal Theorem. 
The working deflection $D_{F 5}$ is the net working deflection of $F_{5}$ on both cantilever beams in the structure. Since there is no net deflection between the beams connected at the end, $\mathbb{P}_{\mathrm{F} 5}$ should be zero. Thus,

$$
\begin{aligned}
0 & =D_{F 5} \equiv\left(D_{F}\right)_{51} \equiv \Sigma_{i}\left(A_{F}\right)_{5 i}(F)_{i l} \\
& =\left(0.2408 F_{1}+0.94471 F_{2}-2.95355 F_{3}-0.43481 F_{4}+5.654975 F_{5}\right) \times 10^{-6} \text { in. } / 1 \mathrm{lb}
\end{aligned}
$$

This equation is used to obtain the nonworking (redundant) force $F_{5}$ in terms of the working (nonredundant) forces $\mathrm{F}_{1}$ to $\mathrm{F}_{4}$. Solving for $\mathrm{F}_{5}$ gives

$$
F_{5}=-0.042,582 F_{1}-0.167,058 F_{2}+0.522,292 F_{3}+0.076,890 F_{4} .
$$

By use of this equation, the net-working deflections of the other forces $F_{1}$ to $F_{4}$ can be obtained; for example,

$$
\begin{aligned}
D_{F l} & =\Sigma_{i}\left(A_{F}\right)_{l i}(F)_{i l} \\
& =\left[0.1295 F_{1}+0.21295 F_{2}+(0) F_{3}+(0) F_{4}\right. \\
& \left.+0.2408\left(-0.042,582 F_{1}-0.167,058 F_{2}+0.522,292 F_{3}+0.076,890 F_{4}\right)\right] \times 10^{-6} \mathrm{in.} / 1 b \\
& =\left(0.119,246 F_{1}+0.172,722 F_{2}+0.125,768 F_{3}+0.018,515 F_{4}\right) \times 10^{-6} \mathrm{in.} / 1 b .
\end{aligned}
$$

Similarly,

$$
\mathrm{D}_{\mathrm{F} 2}=\left(0.172,722 \mathrm{~F}_{1}+0.617,239 \mathrm{~F}_{3}+0.493,414 \mathrm{~F}_{3}+0.072,639 \mathrm{~F}_{4}\right) \times 10^{-6} \mathrm{in} . / \mathrm{b} \text {, }
$$

and so forth. The resulting flexibility matrix for the net working deflection is thus determined. Let

$$
(W)=\begin{array}{|c|}
\hline F_{1} \\
\hline F_{2} \\
\hline F_{3} \\
\hline F_{4} \\
\hline
\end{array}
$$

and

$$
\left(D_{W}\right)=\begin{array}{|l|}
\hline D_{W 1} \\
\hline D_{W 2} \\
\hline D_{W 3} \\
\hline D_{W 4} \\
\hline
\end{array}
$$

Then, the flexibility matrix in the equation

$$
\left(D_{W}\right)=\left(A_{W}\right) \times(W)
$$


is

$\left(\mathrm{A}_{\mathrm{W}}\right)=$\begin{tabular}{|c|c|c|c|}
\hline $0.119,246$ & $0.172,722$ & $0.125,768$ & $0.081,515$ \\
\hline $0.172,722$ & $0.617,239$ & $0.493,414$ & $0.072,639$ \\
\hline $0.125,768$ & $0.493,414$ & $0.481,347$ & $0.097,162$ \\
\hline $0.018,515$ & $0.072,639$ & $0.087,162$ & $0.069,727$ \\
\hline
\end{tabular}

This checks Eq (5) in WAPD-115 to slide rule accuracy.

Systematic Load Calculation

A systematic way to calculate $\left(A_{W}\right)$ is to use the concept of partitioned matrices. The original flexibility matrix equation for the statically determinate free bodies is

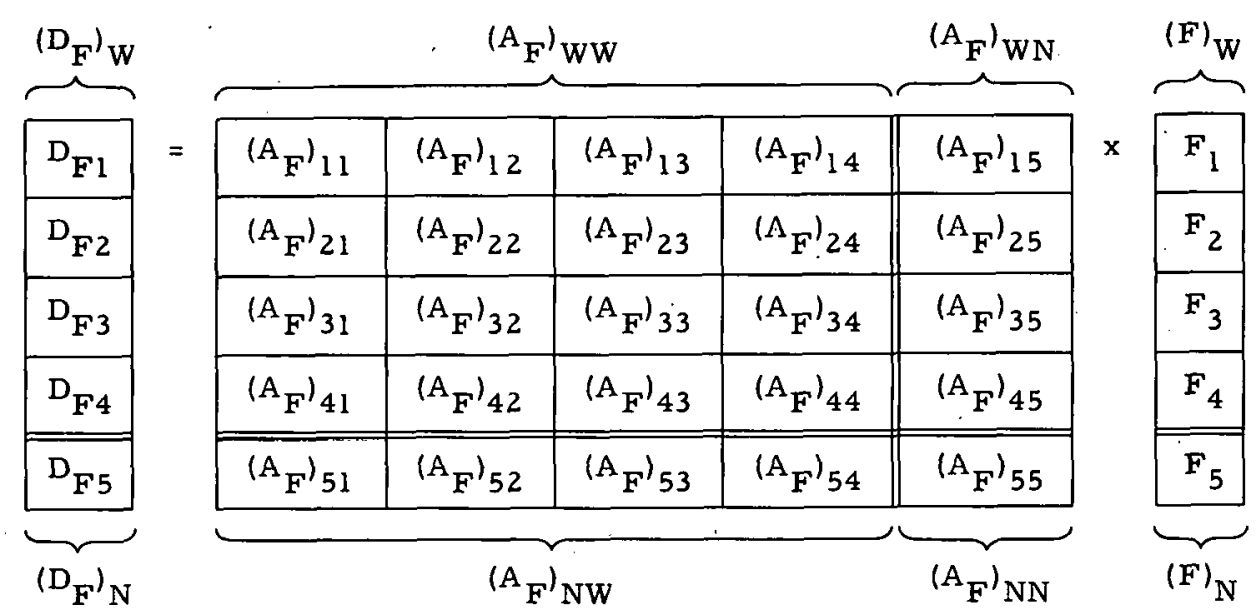

It is to be noted that double lines partition the se matrices into working (W) and nonworking (N) blocks, and that these blocks can be used in separated matrix equations; that is, .

$$
\begin{array}{|l|}
\hline\left(D_{F}\right)_{W} \\
\hline\left(D_{F}\right)_{N} \\
\hline
\end{array}=\begin{array}{|l|l|}
\hline\left(A_{F}\right)_{W W} & \left(A_{F}\right)_{W N} \\
\hline\left(A_{F}\right)_{N W} & \left(A_{F}\right)_{N N} \\
\hline
\end{array} \times \begin{array}{|l|}
\hline F)_{W} \\
\hline(F)_{N} \\
\hline
\end{array}
$$

can be expressed as

$$
\left(D_{F}\right)_{W}=\left(A_{F}\right)_{W W} \times(F)_{W}+\left(A_{F}\right)_{W N} \times(F)_{N}
$$

atid

$$
\left(D_{F}\right)_{N}=\left(A_{F}\right)_{N W} \times(F)_{W}+\left(A_{F}\right)_{N N} \times(F)_{N}
$$

Setting $\left(D_{F}\right)_{N}=(0)$ gives

$$
(0)=\left(A_{F}\right)_{N W} \times(F)_{W}+\left(A_{F}\right)_{N N} \times(F)_{N}
$$

To solve for the redundant loads $(F)_{N}$, multiply each term by the inverse matrix of $\left(A_{F}\right)_{N N}$; thus

$$
(U)=\left(A_{F}^{I}\right)_{N N} \times\left(A_{F}\right)_{N W} \times(F)_{W}+\left(A_{F}^{T}\right)_{N N} \times\left(A_{F}\right)_{N N} \times\left(F_{N}\right)
$$

so that

$$
\left(F_{N}\right)=-\left(A_{F}^{I}\right)_{N N} \times\left(A_{F}\right)_{N W} \times(F)_{W}
$$


As a check, this matrix equation will be solved numerically. First,

$$
\left(A_{F}\right)_{N N}=\left(A_{F}\right)_{55}=5.654,975 \times 10^{-6} \mathrm{in.} / 1 \mathrm{~b} \text {, }
$$

giving the inverse

$$
\left(A_{F}^{I}\right)_{N N}=0.176,835,44 \times 10^{6} \mathrm{lb} / \mathrm{in} .
$$

Then,

$$
\begin{aligned}
& -\left(A_{F}^{I}\right)_{N N} \times\left(A_{F}\right)_{N W}=-0.176,835,44 \times 10^{6} \mathrm{lb} / \mathrm{in} \\
& \begin{array}{|l|l|l|l|}
\hline 0.2408 & 0.94471 & -2.95355 & -0.43481 \\
\hline
\end{array} \\
& \begin{array}{|l|l|l|l|}
\hline-0.042,582 & -0.167,058 & +0.522,292 & +0.076,890 \\
\hline
\end{array}
\end{aligned}
$$

which checks Eq (26).

Substitution of Eq (29) into Eq (28a) gives

$$
\text { i } \begin{aligned}
\left(D_{F^{\prime}}\right)_{W} & =\left(A_{F}\right)_{W W} \times(F)_{W}+\left(A_{F}\right)_{W N} \times\left[-\left(A_{F}^{I}\right)_{N N} \times\left(A_{F}\right)_{N W} \times(F)_{W}\right] \\
& =\left[\left(A_{F}\right)_{W W}-\left(A_{F}\right)_{W N} \times\left(A_{F}^{I}\right)_{N N} \times\left(A_{F}\right)_{N W}\right] \times(F)_{W} .
\end{aligned}
$$

Since

$$
\left(D_{F}\right)_{W}=\left(D_{W}\right),(F)_{W}=(W) \text {, and }\left(D_{W}\right)=\left(A_{W}\right) \times(W) \text {, }
$$

then,

$$
\left(A_{W}\right)=\left(A_{F}\right)_{W W}-\left(A_{F}\right)_{W N} \times\left(A_{F}^{I}\right)_{N N} \times\left(A_{F}\right)_{N W} \cdot
$$

Numerically,

$\left(A_{W}\right)=$\begin{tabular}{|c|c|c|c|}
\hline 0.1295 & 0.21295 & 0 & 0 \\
\hline 0.21295 & 0.77506 & 0 & 0 \\
\hline \hline 0 & 0 & $2.023,962.5$ & 0.324 .6 \\
\hline 0 & .0 & 0.32426 & 0.10316 \\
\hline
\end{tabular}

\begin{tabular}{|c|}
\hline 0.2408 \\
\hline 0.94471 \\
\hline-2.95355 \\
\hline-0.43481 \\
\hline
\end{tabular}

$=$\begin{tabular}{|l|l|l|l|}
\hline 0.11925 & 0.17272 & 0.12577 & 0.01852 \\
\hline 0.17272 & 0.61724 & 0.49341 & 0.07264 \\
\hline 0.12577 & 0.49341 & 0.48135 & 0.09716 \\
\hline 0.01852 & 0.07264 & 0.09716 & 0.06973 \\
\hline
\end{tabular}

which checks Eq (27). 
B. S0207 Code (CTAC and MODE)

\section{Discussion}

A WOLONTIS-650 code has been developed to calculate the influence deflection coefficients (flexibility matrix) for an elastic structure with up to 10 applied loads and up to 14 loads when the structure is made statically determinate. An estimate is made of the shock response to a $1-\mathrm{g} l o a d-$ ing by using weights as the applied loads, and the fundamental frequency is approximated by the formula (Ref 8 ):

$$
f \cong(2 \pi)^{-1}\left[g\left(\Sigma_{i} W_{i} Y_{i}\right) /\left(\Sigma_{i} W_{i} Y_{i}^{2}\right)\right] 1 / 2
$$

where

$$
\begin{aligned}
& \mathrm{f}=\text { natural frequency, cps, } \\
& \mathrm{g}=386 \text { in. } / \mathrm{sec}^{2}, \text { usually, } \\
& \mathrm{w}_{\mathrm{i}}=\text { weight at point } \mathrm{i}, \\
& \mathrm{Y}_{\mathrm{i}}=\text { static deflection of } \mathrm{w}_{\mathrm{i}} .
\end{aligned}
$$

and

This formula is good if all deflections are positive. Local forces and moments throughout the structure can also be determined. All this is programmed in S0207 deck 1 and is called the CTAC code.

In S0207, deck 2 is programmed the MODE code, which uses the iteration procedure of WAPD- 15 to calculate as many modes of vibration as desired. Local forces and moments for each mode can also be determined.

\section{Arrangement of Decks}

CTAC without MODE: Successive CTAC problems can be run with the following arrangement of cards. (Each arrangement must be specified on the back of the requester card.)

\begin{tabular}{c} 
Specified Arrangement \\
on Requester Card \\
\hline
\end{tabular}

S0207 deck 1

Input deck

\section{Actual Contents of Arrangement} (Not Indicated on Requester Card)

On file in 650 room

$$
\left\{\begin{array}{l}
\text { CTAC transfer card } \\
\text { First CTAC data deck } \\
-- \\
\text { Last CTAC data deck }
\end{array}\right.
$$

CTAC and MODE: The MODE code uses the data from the CTAC code input and output to calculate natural frequencies, mode shapes, and mode amplitudes of an elastic structure. If the MODE problem immediately follows the corresponding CTAC problem, the arrangement of decks is this:

\section{Specified Arrangement on Requester Card}

50207 deck 1

Input deck 1
Actual Contents of Arrangement (Not Indicated on Requester Card)

On file in 650 room

CTAC transfer card First CTAC data deck --

Last CTAC data deck

(Continued) 
Specified Arrangement on Requester Card

S0207 deck 2

Input deck 2
Actual Contents of Arrangement (Not Indicated on Requester Card),

On file in 650 room

MODE data deck cor -

responding to last

CTAC data deck

MODE Alone: If the corresponding CTAC problem had been done on a separate previous occasion, the arrangement of cards is:

\section{Specified Arrangement on Requester Card}

SO20? deck 1

Input deck 1

S0207 deck 2

Input deck 2
Actual Contents of Arrangement (Not Indicated on Requester Card)

On file

CTAC data deck CTAC output deck MOUE transfer card

On file

MODE data deck

\section{Input Cards}

Transfer Cards:

1) CTAC Transfer Card

Columns

$7-10$

$77-79$
Contents

6850

xxx (Arbitrary 3-digit problem identification)

2) MODE Transfer Card

Columns

$7-10$

$77-79$ 5480

Contents

xxx (Arbltrary '3-digil problem identification)

Data Card Format: Each number (called a "word" on a card) has a sign, +or - , and 10 digits, taking up a total of 11 columns on a card. A "fixed" number is put at the right end and is preceded by zeros; for example, +23 (fix) is put on a card as +0000000023. A number that is not fixed is considered to be in the floating form \pm (a. bcdefgh) $\times 10^{i j-50}$ and is put on a card as \pm abcdefghij; for example, -23 is put on a card as -2300000051 , and +0.056 is put on a card as +5600000048 . Standard WOLONTIS format cards are used as shown on the following page. 
Columns

$7-9$

10

$11-21$

$22-32$

$66-76$

\section{Contents}

Location of first word of card in 650 storage drum.

Number of consecutive words on card, 1 to 6 . If a row of words is more than 6 , the row is broken in groups of 6 or less and the groups put on successive cards. For example, if a row of 9 words is to be put on cards starting at location 101, 5 words could be put on a card with location 101 and 4 words could be put.on the next card with location $101+5=106$.

First word

Second word

Sixth word 
CTAC Data Deck (Input)

\begin{tabular}{|c|c|c|c|c|c|}
\hline $\begin{array}{l}\text { Location of } \\
\text { First Word }\end{array}$ & $\begin{array}{c}\text { Number of } \\
\text { Words in Row }\end{array}$ & $\begin{array}{l}\text { First } \\
\text { Word }\end{array}$ & $\begin{array}{l}\text { Second } \\
\text { Word }\end{array}$ & $\begin{array}{l}\text { Third } \\
\text { Word }\end{array}$ & Explanation \\
\hline 638 & $\begin{array}{l}1 . \\
.\end{array}$ & TRA No. 1 & & & $\begin{array}{l}\text { TRA No. } 1=+0203000745 \text {, if there } \\
\text { is a load calculation for this CTAC } \\
\text { problem. } \\
\text { TRA No. } 1=+0203000548 \text {, if there } \\
\text { is no load calculation and if MODE } \\
\text { follows this CTAC problem. } \\
\text { TRA No. } 1=+0203000685 \text {, if there } \\
\text { is no load calculation and if MODE } \\
\text { does not follow this particular } \\
\text { CTAC problem. }\end{array}$ \\
\hline 540 & 3 & $\overline{\mathrm{P}}(\mathrm{fix})$ & $W(\mathrm{fix})$ & $R(f i x)$ & $\begin{array}{l}\bar{P}=\text { total number of elementary } \\
\text { (primitive) strurtures; } 1 \leq \bar{P}<999 \\
W=\text { total number of external loads } \\
\text { (weights) on structure: } 1 \leq W \leq 10 \text {. } \\
R=\text { total number of loads }\left(F_{R}\right) \text { on } \\
\text { statically determinate structure; } \\
W \leq R \leq 14 . \text { The first } W \text { loads of } \\
R \text { are the original external loads. }\end{array}$ \\
\hline & & & & & $\begin{array}{l}\text { Next come } \bar{P} \text { sets of cards for } \bar{P} \\
\text { primitives in order from } P=1 \text { to } \\
P=\bar{P} \text {. }\end{array}$ \\
\hline 543 & 3 & $P(f i x)$ & TRA No. 2 & $N(f i x)$ & $\begin{array}{l}P=\text { number of primitive; } 1 \leq P \leq \bar{P} \\
\text { 'IRA No. } 2=+0203000602 \text {, if par }- \\
\text { tial flexibility matrix } \dot{A}_{R} \text { due to } P \\
\text { primitives is to be punched. } \\
\text { TR No. } 2 \equiv+0203000604 \text { otherwise } \\
N=\text { number of loads on primitive. }\end{array}$ \\
\hline $\begin{array}{l}197 \\
197+N \\
\quad-- \\
197-N+N^{2}\end{array}$ & $\begin{array}{l}\mathrm{N} \\
\mathrm{N}\end{array}$ & $\begin{array}{l}\mathrm{A}_{11} \\
\mathrm{~A}_{21} \\
\mathrm{~A}_{\mathrm{N} 1}\end{array}$ & $\begin{array}{l}\mathrm{A}_{12} \\
\mathrm{~A}_{22} \\
\mathrm{~A}_{\mathrm{N} 2}\end{array}$ & $\begin{array}{l}\text { etc. } \\
\text { etc. } \\
\text { etc. }\end{array}$ & $\begin{array}{l}\text { Flexibility malrix } A_{p} \text { of primitive } \\
\text { structure } P \text {. The first word of each } \\
\text { row must start a new card. }\end{array}$ \\
\hline $\begin{array}{l}246 \\
246+R \\
\cdots \\
246-R+N R\end{array}$ & $\begin{array}{l}\mathrm{R} \\
\mathrm{R} \\
\mathrm{R}\end{array}$ & $\begin{array}{l}\mathrm{C}_{11} \\
\mathrm{C}_{21} \\
\mathrm{C}_{\mathrm{N} 1}\end{array}$ & $\begin{array}{l}\mathrm{C}_{12} \\
\mathrm{C}_{22} \\
\mathrm{C}_{\mathrm{N} 2}\end{array}$ & $\begin{array}{l}\text { etc. } \\
\text { etc. } \\
\text { etc. }\end{array}$ & $\begin{array}{l}\text { Connection matrix } C p \text { giving } \\
\left(F_{P}\right)=\left(C_{p}\right) \times\left(F_{R}\right) \text {. The first word } \\
\text { of each row must start a new card. }\end{array}$ \\
\hline
\end{tabular}


CTAC Data Deck (Input), Cont.

\begin{tabular}{|c|c|c|c|c|c|}
\hline $\begin{array}{l}\text { Location of } \\
\text { First Word }\end{array}$ & $\begin{array}{l}\text { Number of } \\
\text { Words in Row }\end{array}$ & $\begin{array}{l}\text { First } \\
\text { Word }\end{array}$ & $\begin{array}{l}\text { Second } \\
\text { Word }\end{array}$ & $\begin{array}{l}\text { Third } \\
\text { Word }\end{array}$ & Explanation \\
\hline & & & & & $\begin{array}{l}\text { These cards come after the P sets } \\
\text { of cards. }\end{array}$ \\
\hline \multirow[t]{2}{*}{$\begin{array}{l}515 \\
500 \\
\end{array}$} & $\begin{array}{c}w \\
1\end{array}$ & $\begin{array}{c}w_{1} \\
g\end{array}$ & $\mathrm{w}_{2}$ & etc. & $\begin{array}{l}\text { Weights (pounds force) } \\
\text { Gravity = } 386 \text { in. } / \mathrm{sec}^{2}\end{array}$ \\
\hline & & . & & & $\begin{array}{l}\text { If there are to be load calculations } \\
\text { on some primitives, the following } \\
\text { sets of cards must be added to the } \\
\text { deck. Otherwise, they are not used. } \\
\text { There is one set of cards for each } \\
\text { primitive to be considered, and } \\
\text { these primitives need not be the } \\
\text { same as before. }\end{array}$ \\
\hline 543 & 3 & $P(f i x)$ & TRA No. 3 & $N(f i x)$ & $\begin{array}{l}\text { TRA No. } 3=+0203000769 \text {, if this is } \\
\text { not the last primitive on which load } \\
\text { calculations are made. } \\
\text { TRA No. } 3=+0203000548 \text {, if this is } \\
\text { the last primitive considered, and } \\
\text { if MODE follows. } \\
\text { TRA No. } 3=+0203000685 \text {, if this is } \\
\text { the last primitive considered and if } \\
\text { CTAC follows or if the end of the } \\
\text { last problem. }\end{array}$ \\
\hline 197 & $\mathrm{~N}$ & $A_{11}$ & $A_{12}$ & etc. & Flexibility matrix $A_{p}$ \\
\hline $246--$ & $\begin{array}{l}\mathbf{R} \\
\mathbf{R}\end{array}$ & $\begin{array}{l}C_{11} \\
C_{R 1}\end{array}$ & $\begin{array}{l}\mathrm{C}_{12} \\
\mathrm{C}_{\mathrm{R} 2}\end{array}$ & $\begin{array}{l}\text { etc. } \\
\text { etc. }\end{array}$ & Conncction matrix $\mathrm{C}_{\mathrm{p}}$. \\
\hline
\end{tabular}


MODE Data Deck (Input)

\begin{tabular}{|c|c|c|c|c|c|}
\hline $\begin{array}{l}\text { Location of } \\
\text { First Word }\end{array}$ & $\begin{array}{c}\text { Number of } \\
\text { Words in Row }\end{array}$ & $\begin{array}{l}\text { First } \\
\text { Word }\end{array}$ & $\begin{array}{c}\text { Second } \\
\text { Word }\end{array}$ & $\begin{array}{l}\text { Third } \\
\text { Word }\end{array}$ & Explanation \\
\hline : & $\begin{array}{l}2 \\
:\end{array}$ & $\mathbf{E}$ & $\mathrm{T}$ & & $\begin{array}{l}E=\text { relative error for conver }- \\
\text { gence in iterations }\left(10^{-6} \text { cor - }\right. \\
\text { responds to an error in the } 7 \text { th } \\
\text { digit of a number }) \mathrm{T}=\text { total } \\
\text { number of iterations carried out } \\
\text { if results do not converge, say } \\
15 .\end{array}$ \\
\hline 327 & 3 & $\mathrm{v}_{\mathrm{o}}$ & $f_{0}$ & $M(f i x)$ & $\begin{array}{l}\mathrm{V}_{\mathrm{o}}=\text { maximum starting velocity, } \\
\mathrm{f}_{\mathrm{o}}=\text { cutoff natural frequency, } \\
\text { cps } \\
\mathrm{M}=\text { number of modes to be } \\
\quad \text { calculated; } \mathrm{l} \leq \mathrm{M} \leq \mathrm{W} . \\
\text { The starting velocity } \mathrm{V} \text { for each } \\
\text { mode of frequency } \mathrm{f} \text { is deter - } \\
\text { mined by the formulas } \\
\qquad \begin{array}{l}\mathrm{V}=\mathrm{V}_{\mathrm{o}} \text { if } \mathrm{f} \leq \mathrm{f}_{\mathrm{o}} \\
\mathrm{V}=\mathrm{f}_{\mathrm{o}} \mathrm{V}_{\mathrm{o}} / \mathrm{f} \text { if } \mathrm{f}>\mathrm{f}_{\mathrm{o}} .\end{array}\end{array}$ \\
\hline . & & & & & $\begin{array}{l}\text { If there are to be load ralcula- } \\
\text { tiuns on some primitives, the } \\
\text { following sets of cards must be } \\
\text { used. These cards have pre- } \\
\text { cisely the same format af in thr } \\
\text { CTAC data deck. }\end{array}$ \\
\hline 543 & 3 & $P(f i x)$ & TRA No. 3 & $N(f i x)$ & \\
\hline 197 & $\begin{array}{l}\mathrm{N} \\
\mathrm{N}\end{array}$ & $\begin{array}{l}\dot{\mathrm{A}}_{11} \\
\mathrm{~A}_{\mathrm{N} 1}\end{array}$ & $\begin{array}{l}\mathrm{A}_{12} \\
\mathrm{~A}_{\mathrm{N} 2}\end{array}$ & $\begin{array}{l}\text { etc. } \\
\text { etc. }\end{array}$ & \\
\hline $\begin{array}{ll}246 & \\
246-R+i N R\end{array}$ & $\begin{array}{l}\mathbf{R} \\
\mathbf{R}\end{array}$ & $\begin{array}{l}\mathrm{C}_{11} \\
\mathrm{C}_{\mathrm{Nl}}\end{array}$ & $\begin{array}{l}\mathrm{C}_{12} \\
\mathrm{C}_{\mathrm{N} 2}\end{array}$ & $\begin{array}{l}\text { etc. } \\
\text { etc. }\end{array}$ & \\
\hline
\end{tabular}




\section{Output Cards}

Output Card Format: Most of the outpurt is in the form of blocks of data (matrices). Before each matrix is printed out, three words in locations 997 to 999 give, respectively, the machine storage location of the first element of the matrix, the number of rows, and the number of columns.

If the structure is redundant, one of the matrices will contain the flexibility matrix ${ }^{A}{ }_{W}$ of the applied loads and the coefficients of the redundant forces in terms of the applied loads. This matrix is identified by ones along the lower right diagonal. For example, if a structure has $R=4$ loads when made statically determinate and $W=2$ applied loads, this matrix will be in the form:

\begin{tabular}{|c|c|c|c|}
\hline$A_{11}$ & $A_{12}$ & $X$ & $X$ \\
\hline$A_{21}$ & $A_{22}$ & $X$ & $X$ \\
\hline$K_{31}$ & $K_{32}$ & -1 & $X$ \\
\hline$K_{41}$ & $K_{42}$ & $K_{43}$ & -1 \\
\hline
\end{tabular}

where the corresponding equations are

$$
\begin{aligned}
& D_{F 1}=A_{11} F_{1}+A_{12} F_{2}, \\
& D_{F 2}=A_{21} F_{1}+A_{22} F_{2} . \\
& F_{3}=K_{31} F_{1}+K_{32} F_{2} .
\end{aligned}
$$

and

$$
F_{4}=K_{41} F_{1}+K_{42} F_{2}+K_{43} F_{3}
$$




\begin{tabular}{|c|c|c|c|c|c|c|}
\hline \multicolumn{7}{|c|}{ CTAC Output Deck } \\
\hline $\begin{array}{l}\text { Location of } \\
\text { First Word }\end{array}$ & $\begin{array}{c}\text { Number of } \\
\text { Words in Row }\end{array}$ & $\begin{array}{l}\text { First } \\
\text { Word }\end{array}$ & $\begin{array}{l}\text { Second } \\
\text { Word }\end{array}$ & $\begin{array}{l}\text { Third } \\
\text { Word }\end{array}$ & $\begin{array}{l}\text { Fourth } \\
\text { Word }\end{array}$ & Explanation \\
\hline & & & & & & $\begin{array}{l}\text { If TRA No. } 2 \text { for primitive } P \text { is } \\
+0203000602 \text {, the following cards } \\
\text { are punched: }\end{array}$ \\
\hline 540 & 4 & $\overline{\mathrm{P}}(\mathrm{fix})$ & $W($ fix $)$ & $R(f i x)$ & $P(f i x)$ & \\
\hline 9.97 & 3 & 001 (fix) & $R(f i x)$ & $R(f i x)$ & & $\begin{array}{l}\text { Flexibility matrix } A_{R} \text { of } R \text { loads } \\
\text { due to } P \text { primitive. }\end{array}$ \\
\hline 997 & $3:$ & 001 (fix) & $\mathbf{R}(\mathbf{f i x})$ & $R($ fix $)$ & & $\begin{array}{l}\text { If the structure is redundant } \\
\text { (W }=\mathrm{R} \text { ), this matrix containing } \\
{ }^{A}{ }_{W} \text { and confficients } \mathrm{K}_{\mathrm{ij}} \text { is } \\
\text { punched. }\end{array}$ \\
\hline 540 & 3 & $\overline{\mathrm{P}}(\mathrm{fix})$ & $W(f i x)$ & $\mathbf{R}(\mathrm{fix})$ & & \\
\hline $997=$ & 3 & $.001(f i x)$ & $W(f i x)$ & $W(f i x)$ & & $\begin{array}{l}\text { Flexibility matrix } A_{W} \text { of applied } \\
\text { loads. }\end{array}$ \\
\hline 501 & $\dot{w}$ & $Y_{1}$ & $\mathrm{Y}_{2}$ & etc. & & Static deflections of weights, in. \\
\hline 529 & 3 & $Y_{\mathbf{s}}$ & $2 \pi f$ & f & & $\begin{aligned} \mathrm{Y}_{\mathrm{S}} & =\text { equivalent static deflection } \\
& =\left(\Sigma_{\mathrm{i}} \mathrm{W}_{\mathrm{i}} \mathrm{Y}_{\mathrm{i}}^{2}\right) /\left(\Sigma_{\mathrm{i}} \mathrm{W}_{\mathrm{i}} \mathrm{Y}_{\mathrm{i}}\right) \\
2 \pi \mathrm{f} & =\text { natural angular frequency } \\
& =\sqrt{\mathrm{g} / \mathrm{Y}_{\mathrm{S}}} \mathrm{rad} / \mathrm{sec} \\
\mathrm{f} & =\text { frequency, cps }\end{aligned}$ \\
\hline $515+\dot{W}$ & $\bar{R}-\mathbf{W}$ & $F_{W+1}$ & $\mathrm{~F}_{\mathrm{W}+2}$ & etc. & & $\begin{array}{l}\text { If } \mathrm{W}<\mathrm{R} \text {, these redundant loads } \\
\text { produced by } 1 \mathrm{~g} \text { applied loads are } \\
\text { punched. }\end{array}$ \\
\hline & $\therefore$ & & & · & & $\begin{array}{l}\text { If load calculations were made } \\
\text { for a primitive, the following oct } \\
\text { of cards is punched for this } \\
\text { primitive. }\end{array}$ \\
\hline 543 & 3 & $P(f i x)$ & TRA No. 3 & $N(f i x)$ & & \\
\hline 997 & 3 & $351(f i x)$ & $N($ fix $)$ & 1 (fix) & & $\begin{array}{l}\text { Matrix of primitive loads unde } i \\
\text { l g applied loar. }\end{array}$ \\
\hline 997 & 3 & $371(f i x)$ & $N($ fix $)$ & $1(f i x)$ & & $\begin{array}{l}\text { Matrix of primitive deflections } \\
\text { under } \downarrow \text { g applied load. }\end{array}$ \\
\hline
\end{tabular}


MODE Output Deck

\begin{tabular}{|c|c|c|c|c|c|c|}
\hline $\begin{array}{l}\text { Location of } \\
\text { First Word }\end{array}$ & $\begin{array}{l}\text { Number of } \\
\text { Words } \\
\text { in Row }\end{array}$ & $\begin{array}{l}\text { First } \\
\text { Word }\end{array}$ & $\begin{array}{l}\text { Second } \\
\text { Word }\end{array}$ & $\begin{array}{l}\text { Third } \\
\text { Word }\end{array}$ & $\begin{array}{l}\text { Fourth } \\
\text { Word }\end{array}$ & Explanation \\
\hline . & & & . & & & $\begin{array}{l}\text { The following cards are } \\
\text { punched for each mode calcu- } \\
\text { lated. }\end{array}$ \\
\hline 330 & 3 & $2 \pi f_{J}$ & $\mathbf{f}_{\mathbf{J}}$ & $\mathrm{V}_{\mathbf{J}}$ & $J(f i x)$ & $\begin{aligned} 2 \pi f_{J} & =\text { Nat ang freq, rps } \\
f_{J} & =\text { Nat frequency, cps } \\
V_{J} & =\text { starting velocity, ips } \\
J & =\text { mode; } J=1 \text { to } M .\end{aligned}$ \\
\hline 336 & 3 & $\mathbf{T}_{\mathbf{J}}$ & $E$ & $\mathrm{~T}$ & & $\begin{aligned} \mathrm{T}_{\mathrm{J}}= & \text { number of iterations in } \\
& \text { calculation of mode } \mathrm{J} .\end{aligned}$ \\
\hline 297 & W & $F_{1 J}^{\prime}$ & $\mathbf{F}_{2 \mathrm{~J}}^{\prime}$ & etc. & & $\begin{aligned} F_{I J}^{\prime}= & \text { force } F_{I} \text { in mode } J \text { after } \\
& T_{J} \text { iterations, } 1 b .\end{aligned}$ \\
\hline 307 & W & $F_{1 J}^{\prime \prime}$ & $F_{2 J}^{\prime \prime}$ & etc. & & $\begin{aligned} F_{I J}^{\prime !}= & \text { force } F_{I} \text { in mode } J \text { after } \\
& T_{J}-1 \text { iterations, } 1 b .\end{aligned}$ \\
\hline 317 & W & $F_{1 J}^{\prime \prime \prime}$ & $F_{2 J}^{\prime \prime \prime}$ & etc. & & $F_{I J}^{\prime \prime \prime}=\left(W_{I} / g\right)\left(2 \pi f_{J}\right)^{2} Y_{I J} ; l b$. \\
\hline \multirow[t]{2}{*}{484} & w & $\mathrm{Y}_{1 \mathrm{~J}}$ & $\mathrm{Y}_{2 \mathrm{~J}}$ & etc. & & $Y_{I J}=$ deflection of $F_{I J}$, in. \\
\hline & & & & & & $\begin{array}{l}\text { If } W<R \text {, the following cards } \\
\text { are punched. }\end{array}$ \\
\hline 997 & 3 & $\begin{array}{l}344+W M \\
\quad(f i x)\end{array}$ & $l(f i x)$ & $M(f i x)$ & & $\begin{array}{l}\text { Matrix of } F_{W+1} \text {, first redun- } \\
\text { dant load. }\end{array}$ \\
\hline-- & -- & - & -- & -- & $\cdots$ & -- \\
\hline \multirow[t]{2}{*}{997} & 3 & {$[344+R M-M]$} & 1 (fix) & $M(f i x)$ & & $\begin{array}{l}\text { Matrix of } F_{R J} \text {, last redundant } \\
\text { load. }\end{array}$ \\
\hline & & & & & - & $\begin{array}{l}\text { If load calculations were made } \\
\text { for a primitive, the following } \\
\text { set of cards are punched for } \\
\text { each primitive. }\end{array}$ \\
\hline 543 & 3 & $P(f i x)$ & TRA No. 3 & $N(f i x)$ & & $\bar{i}$ \\
\hline 997 & 3 & 010 (fix) & $N(f i x)$ & $M(f i x)$ & & $\begin{array}{l}\text { Matrix of primitive loads; } \\
\left(\mathrm{F}_{\mathrm{P}^{\prime} \mathrm{IJ}^{*}}\right.\end{array}$ \\
\hline 997 & 3 & 080 (fix) & $N(f i x)$ & $M(f i x)$ & & $\begin{array}{l}\text { Matrix of primitive 'deflections: } \\
\left(D_{F P}\right)^{\prime} J^{\prime}\end{array}$ \\
\hline
\end{tabular}


Printout of Cards: The printout of the cards used in the determination of influence coefficients and modes of vibration starts on page 32. The S0207 input cards were sent to the IBM -650 operator with the following note on the back of the requester card:

\section{Order of Cards \\ S0207 deck 1 \\ Input deck 1 \\ S0207 deck 2 \\ Input deck 2}

Results: The CTAC output gives an estimated natural frequency of $223.50 \mathrm{cps}$, which compares well with the first MODE frequency of $222.45 \mathrm{cps}$. For a natural frequency of $223.5 \mathrm{cps}$, the shock acceleration factor corresponding to a unit starting velocity is

$$
\mathrm{N}=\frac{2 \pi \mathrm{fV}}{E}=\frac{2\left(223.5 \mathrm{sec}^{-1}\right)\left(1 \mathrm{in} . \mathrm{sec}^{-1}\right)}{(386 \mathrm{L11.} \mathrm{sec})}=3.658 \text {. }
$$

Thus, from the CTAC output, the moment at the left end of the outer cylinder is

$$
M_{0}=(7688.1 \text { in. }-1 b)(3.638)=27,969 \text { in. }-1 b \text {. }
$$

and the absolute sum of the four MODE results is

$$
M_{0}=(27,315+1,118+4686+375) \text { in. }-1 b=33,494 \text { in. }-1 b \text {. }
$$

The MODE code gives a higher moment but, in the usual shock calculations, the higher modes have smaller starting velocities so that the results will be closer.

From CTAC output, the moment at the left end of the inner cylinder is

$$
M_{i}=(2936.5 \text { in. }-1 b)(3.638)=10,683 \text { in. }-1 \mathrm{~b} \text {, }
$$

and the absolute sum of the four MODE results is

$$
M_{i}=(9131+1537+4500+1978) \text { in. }-1 b=17,146 \text { in. }-1 b \text {. }
$$

As before, taking only two modes would give a closer check.

A direct comparison of mode calculations from WAPD-115 and from the code 50207 is given in the table on the following page.

The odd numbered modes are not so accurate in slide rule calculations because of small differences between large numbers in the determination of $\mathrm{C}_{\mathrm{J}}$. Otherwise, the agreement is satisfactory.

Sample Problem Cards: The actual cards used in the solution of the sample problem given in WAPD-115 are found on pages 32 through 43 of this report. 
COMPARISON TABLE OF MODE CALCULATIONS

\begin{tabular}{|c|c|c|c|c|c|}
\hline Mode J. & 1 & 2 & 3 & 4 & Source \\
\hline $\mathrm{C}_{\mathrm{J}}$ for $\mathrm{V}_{\mathrm{J}}=1 \mathrm{in} . / \mathrm{sec}$ & 121.8 & -134.8 & 1776 & -298.2 & \multirow{9}{*}{$\begin{array}{l}\text { From WAPD-115 } \\
\text { (Slide-rule } \\
\text { accuracy) }\end{array}$} \\
\hline$F_{I J}=C_{J} e_{I J}$ & 122 & -135 & 1776 & -298 & \\
\hline & 755 & -215 & -691 & 518 & \\
\hline (lb) & 699 & 259 & 30 & -644 & \\
\hline & 80 & 164 & 1067 & 823 & \\
\hline \multirow[t]{3}{*}{$\mathrm{D}_{\mathrm{FIJ}}=\mathrm{C}_{\mathrm{J}} \mathrm{a}_{\mathrm{IJ}}$} & 234 & -18 & & & \\
\hline & 837 & -16 & -26 & & \\
\hline & 734 & 18 & 1 & -14 & \\
\hline$\left(10^{6}\right.$ in. $)$ & 130 & 18 & 60 & 27 & \\
\hline$F_{I J}$ & 122 & -148 & 1779 & -291 & \multirow{8}{*}{$\begin{array}{l}\text { From } \mathrm{SO} 207 \\
\text { (IBM-650 } \\
\text { machine) }\end{array}$} \\
\hline & 757 & -233 & -676 & 534 & \\
\hline (lb) & 698 & 280 & 15 & -662 & \\
\hline . & 80 & 188 & 1061 & 808 & \\
\hline \multirow[t]{3}{*}{$\mathrm{D}_{\mathrm{FIJ}}$} & 235 & -19 & 117 & -11 & \\
\hline & 839 & -17 & -26 & 11 & \\
\hline & 733 & 20 & 1 & -13 & \\
\hline$\left(10^{6}\right.$ in. $)$ & 131 & 21 & 59 & 25 & \\
\hline
\end{tabular}


50207

INPUT

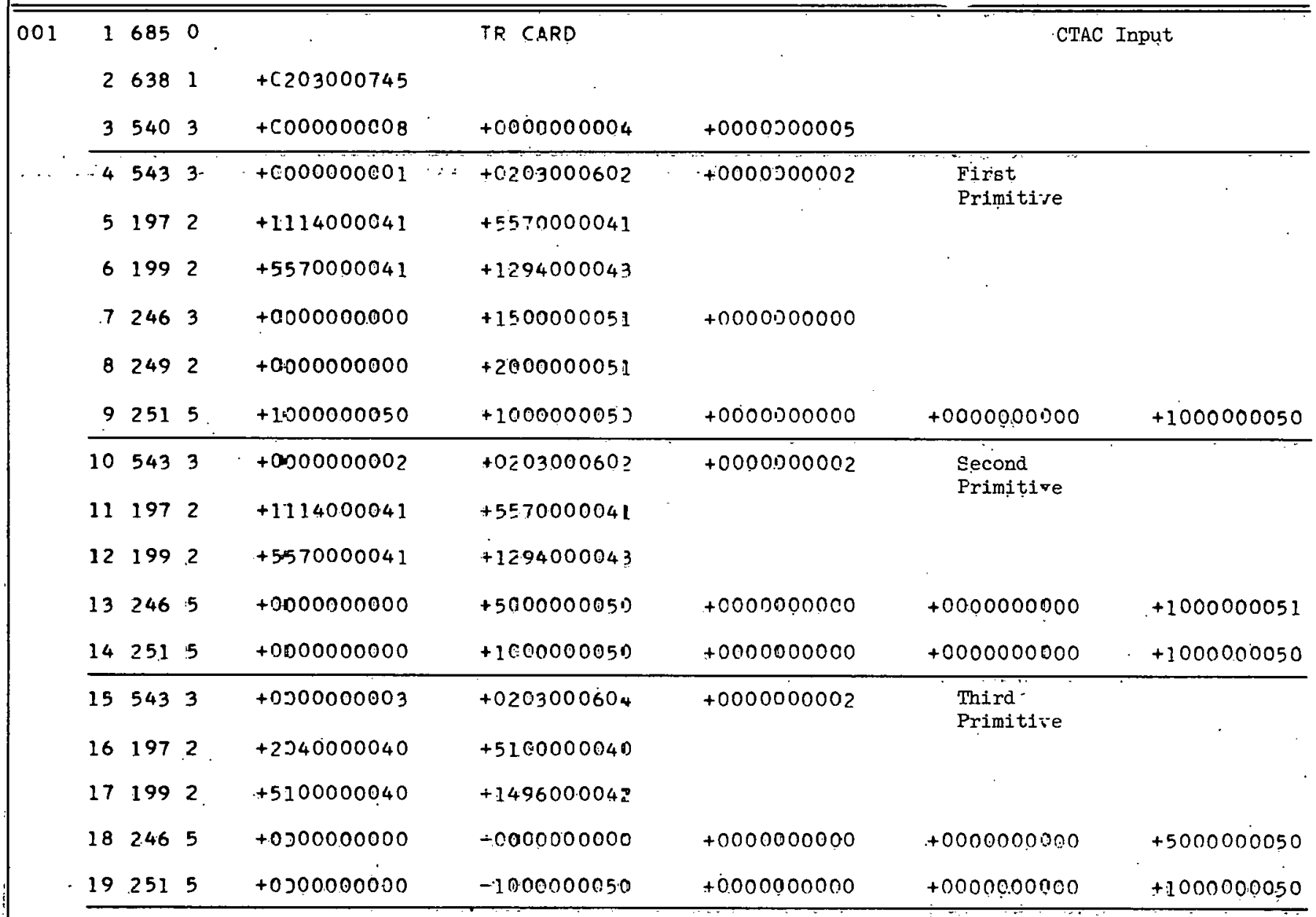




\begin{tabular}{|c|c|c|c|c|c|c|c|}
\hline 20 & 543 & 3 & +0000000004 & +0203000604 & +0000000002 & $\begin{array}{l}\text { Fourth } \\
\text { Primitive }\end{array}$ & \\
\hline 21 & 197 & 2 & +2040000040 & +5100000040 & & & \\
\hline 22 & 199 & 2 & +5100000040 & +1496000042 & & & \\
\hline 23 & 246 & 5 & +0000000000 & +0000000000 & +0000000000 & +0000000000 & +0000000000 \\
\hline 24 & 251 & 5 & +0000000000 & +0000000000 & +0000000000 & +0000000000 & +1000000050 \\
\hline 25 & 543 & 3 & +0000000005 & +0203000604 & +0000000002 & $\begin{array}{l}\text { Fifth } \\
\text { Primitive }\end{array}$ & \\
\hline 26 & 197 & 2 & +3930000041 & +1474000042 & & & \\
\hline 27 & 199 & 2 & +1474000042 & +1331600043 & & & \\
\hline 28 & 246 & 5 & +0000000000 & +0000000000 & +1500000051 & +0000000000 & -2250000051 \\
\hline 29 & 251 & 5 & +0000000000 & +0000000000 & $+100000005 C$ & +1000000050 & -1000000050 \\
\hline 30 & 543 & 3 & +0000000006 & +0203000604 & +0000000002 & $\begin{array}{l}\text { Sixth } \\
\text { Primitive }\end{array}$ & \\
\hline 31 & 197 & 2 & +3930000041 & +147.4000042 & & & . \\
\hline 32 & 199 & 2 & +1474000042 & +1031600043 & & & \\
\hline 33 & 246 & 5 & +00000.00000 & +0000000000 & $+750000005 \mathrm{C}$ & +0000000000 & -1500000051 \\
\hline 34 & 251 & 5 & +0000000000 & $+0 E 00000000$ & +1000000050 & +0000000000 & -1000000050 \\
\hline
\end{tabular}




\begin{tabular}{|c|c|c|c|c|c|c|c|}
\hline 35 & 543 & 3 & +0000000007 & +0203000604 & +0000000002 & $\begin{array}{l}\text { Séventh } \\
\text { Primitzve }\end{array}$ & \\
\hline 36 & 197 & 2 & +1510000041 & $=6040000041$ & & & \\
\hline 37 & 199 & 2 & +6340000041 & $\div 4903000042$ & & & \\
\hline 38 & 246 & 5 & +0200000000 & -0000000000 & +0000000000 & +0000000000 & -7500000050 \\
\hline-39 & 251 & $-5 \cdots$ & +0500000000 & $=0000000000$ & +1000000050 & +0000009000 & -1000000050 \\
\hline 40 & 543 & 3 & +0500000008 & -0203000602 & +0000000002 & $\begin{array}{l}\text { Last } \\
\text { Primitive. }\end{array}$ & \\
\hline 41 & 197 & 2 & +1510000041 & -6040000041 & & & \\
\hline 42 & 199 & 2 & $+6 j 40000041$ & -4903000042 & & & \\
\hline 43 & 246 & 5 & +0500000000 & $\div 0000000000$ & +0000000000 & +0000000000 & +0000000000 \\
\hline 44 & 251 & 5 & $+0,500000000$ & -0000000000 & +0000000000 & $+000000 J 000$ & -1000000050 \\
\hline $4 \dot{5}$ & 515 & 4 & +1325800052 & -1784400052 & +1882000052 & +1204400052 & Weights \\
\hline 46 & 500 & 1 & +3360000052 & Gravity & & & \\
\hline 47 & 543 & 3 & +0.000000001 & +0203000769 & +00000100003 & \multirow{4}{*}{\multicolumn{2}{|c|}{$\begin{array}{l}\text { First Prinftive in } \\
\text { Load Calculation } \\
\text { (including the } \\
\text { founiction moment) }\end{array}$}} \\
\hline 48 & 197 & 3 & +1.114000041 & +5570000041 & +0000000000 & & \\
\hline 49 & 200 & 3 & +5570000041 & +1294000043 & +0000000000 & & \\
\hline 50 & 203 & 3 & +0000000000 & +0000000000 & +0000000000 & & \\
\hline 51 & 246 & 5 & $+0,300000030$ & +1500000051 & +0000000000 & +0000000000 & +2000000051 \\
\hline 52 & 251 & 3 & +1000000050 & +1000000050 & $+0000 \mathrm{C} 00000$ & +0000000000 & +1000000050 \\
\hline 53 & 256 & 5 & +1000000051 & +2500000051 & +0.0000000000 & +0000000000 & +3000000051 \\
\hline
\end{tabular}




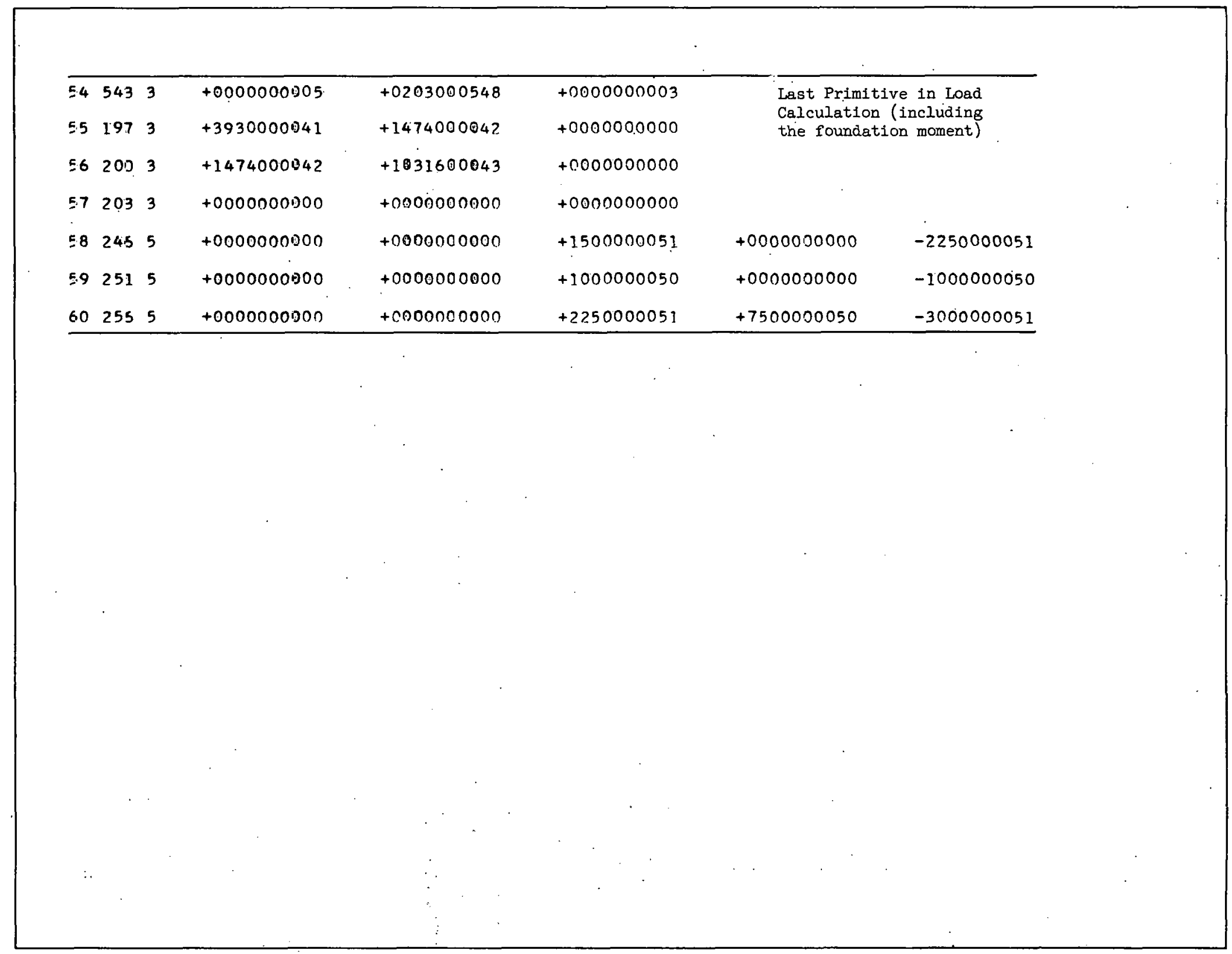




\begin{tabular}{|c|c|c|c|c|c|c|c|}
\hline 61 & 337 & 2 & +1000000044 & +1500000051 & . & \multicolumn{2}{|c|}{ MODI Input } \\
\hline 62 & 327 & 3 & +1000000050 & +1000000056 & +0000000004 & & \\
\hline 63 & 543 & 3 & +0000000001 & +0203000769 & +0000000003 & \multicolumn{2}{|c|}{$\begin{array}{l}\text { First Primltive in Load } \\
\text { Calculstion (same as in CTAC) }\end{array}$} \\
\hline $64^{\circ}$ & 197 & 3. & $+1 \equiv 14000041$ & +5570000041 & +0000000000 & & \\
\hline 65 & 200 & 3 & $\cdots+5570000041 \cdots$ & $\therefore+1.294000043$ & +0000000000 & & \\
\hline 66 & 203 & 3 & $+0<00000000$ & +0000000000 & +0000000000 & & \\
\hline 67 & 246 & 5 & +0000000000 & +1500000051 & +0000000000 & +0000000000 & +2000000051 \\
\hline 68 & 251 & 5 & +1000000050 & +1000000050 & +0000000000 & $+0000000 C \cdot 00$ & +1000000050 \\
\hline 69 & 256 & 5 & +1000000051 & +2500000051 & +0000000000 & $+0000000 \mathrm{r} 00$ & +3000000051 \\
\hline 70 & 543 & 3 & +0000000005 & +0203000548 & +0000000003 & $\begin{array}{l}\text { Last Frimi } \\
\text { Calculatia }\end{array}$ & $\begin{array}{l}\text { tive in Load } \\
\text { (same as in CTAC) }\end{array}$ \\
\hline 71 & 197 & 3 & +3930000041 & +1474000042 & +0000000000 & & \\
\hline 72 & 200 & 3 & +1474000042 & +1031600043 & +0000000000 & & - \\
\hline 73 & 203 & 3 & +0000000000 & +0000000000 & +0000000000 & & \\
\hline 74 & $2: 46$ & 5 & +0000000000 & +0000000000 & +1500000051 & +0000000000 & -2250000051 \\
\hline 75 & 25.1 & 5 & +0000000000 & +0000000000 & +1000000050 & +0000000000 & -1000000050 \\
\hline 76 & 256 & 5 & +0000000000 & +0090000000 & +2250000051 & $+7500000 C 50$ & -3000000051 \\
\hline
\end{tabular}




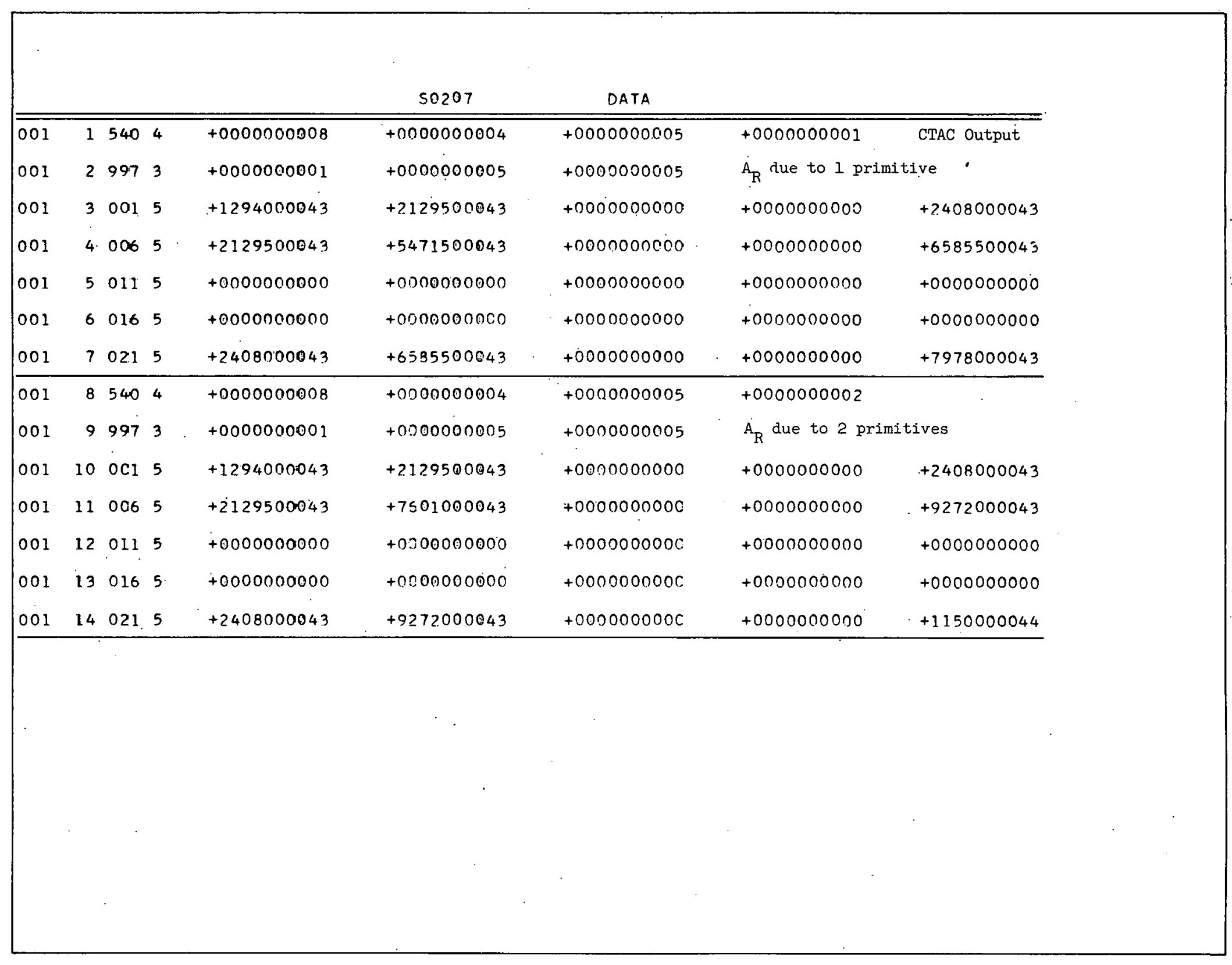




\begin{tabular}{|c|c|c|c|c|c|c|c|c|}
\hline 001 & 15 & 540 & 4 & +3000000008 & $+\cos 00000004$ & +0000000005 & +0000000008 & \\
\hline 001 & 16 & 997 & 3 & +9000000001 & +0000000005 & +0000000005 & $\mathrm{~A}_{\mathrm{R}}$ due to all & îtives \\
\hline 001 & 17 & $00 i$ & 5 & +1294000043 & +2129500043 & +0000000000 & +00000010000 & +2408000043 \\
\hline 001 & 18 & 006 & 5 & +2129500043 & +7750600043 & +0000000000 & +0000030000 & +9447100043 \\
\hline 001 & 19. & 011 & 5 & +2000000000 & +0000000000 & +2023962544 & +3242600043 & -2953550044 \\
\hline 001 & 20 & 016 & 5 & +3000000000 & +0000000000 & +3242600043 & +10316.20043 & -4348100043 \\
\hline 001 & 21 & 021 & 5 & +2408000043 & +9447100043 & -2953550044 & -4348100043 & +5654975044 \\
\hline 001 & 22 & 997 & 3 & +3000000001 & +0000000005 & +0000000005 & $A_{W} \cdot \operatorname{anc} K_{-j}$ & \\
\hline 001 & 23 & 001 & 5 & +1191462643 & +17272.23843 & +125.7679943 & +1851506842 & +2408000043 \\
\hline 001 & 24 & 006 & 5 & +1727223843 & +6172384443 & +4934147743 & +7263858042 & +9447100043 \\
\hline 001 & 25 & 011 & 5 & +1257679943 & +49341.47843 & +4813460043 & +9716208042 & -2953550.044 \\
\hline 001 & 26 & 016 & 5 & +1851506842 & +726385.8042 & +9716208042 & $+697275+042$ & -4348100043 \\
\hline 001 & 27 & 021 & 5 & -4258197448 & -1670582.149 & +5222923149 & $+768898=848$ & -9999999949 \\
\hline
\end{tabular}




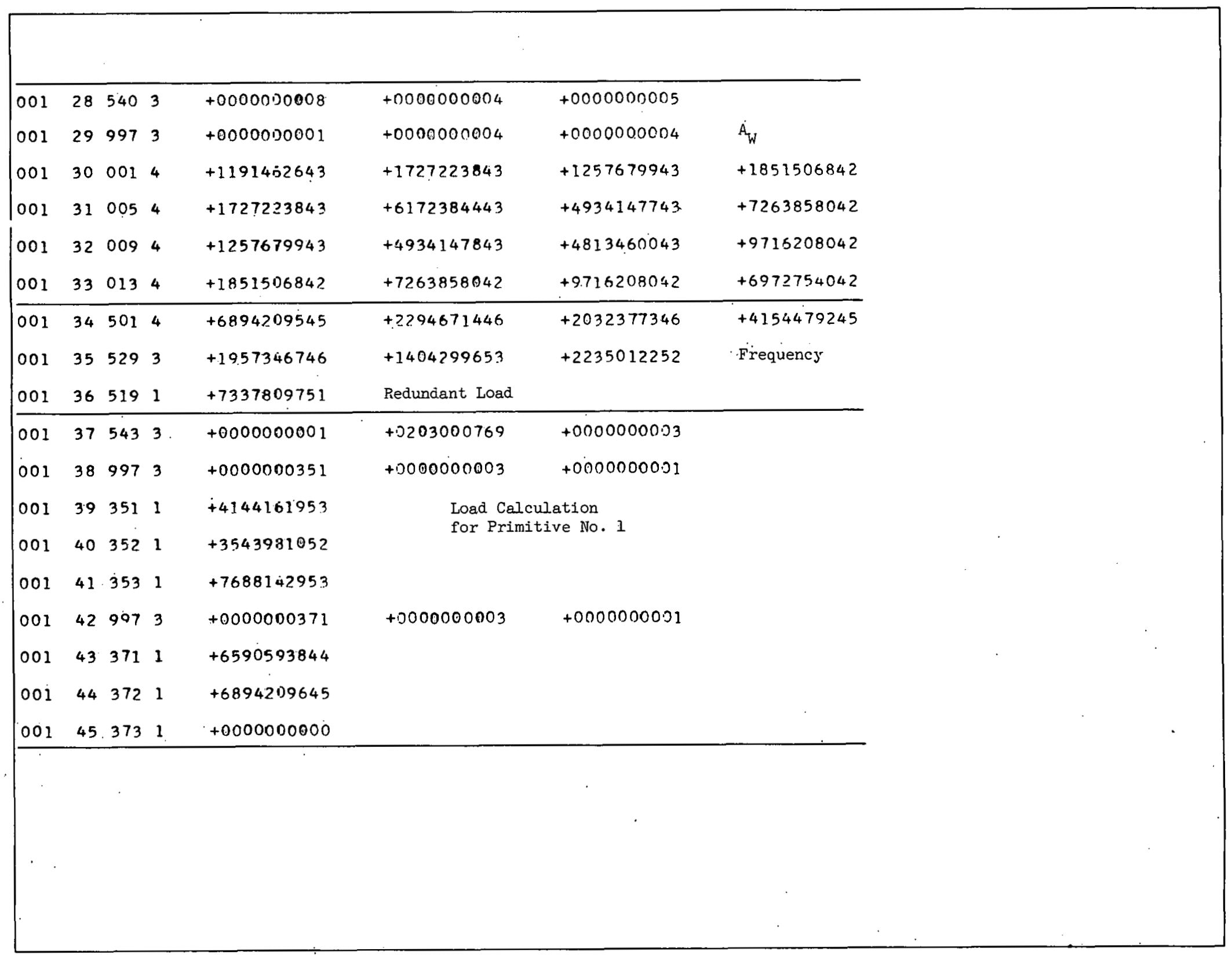




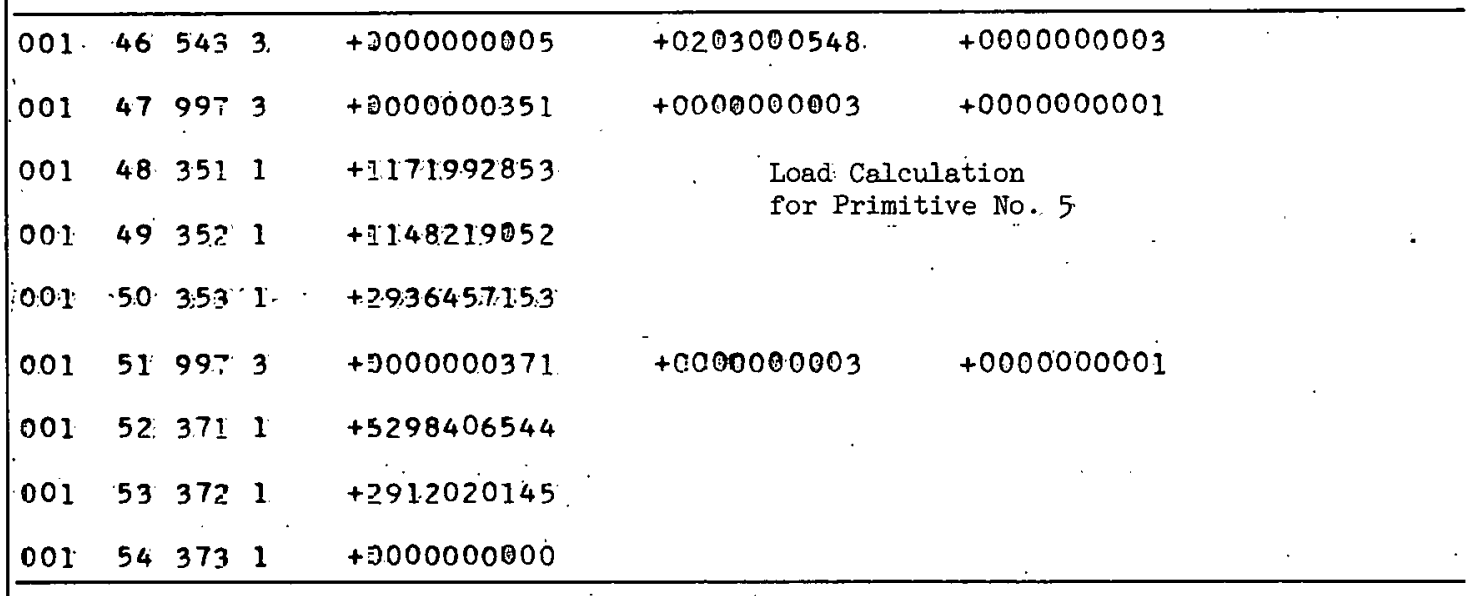

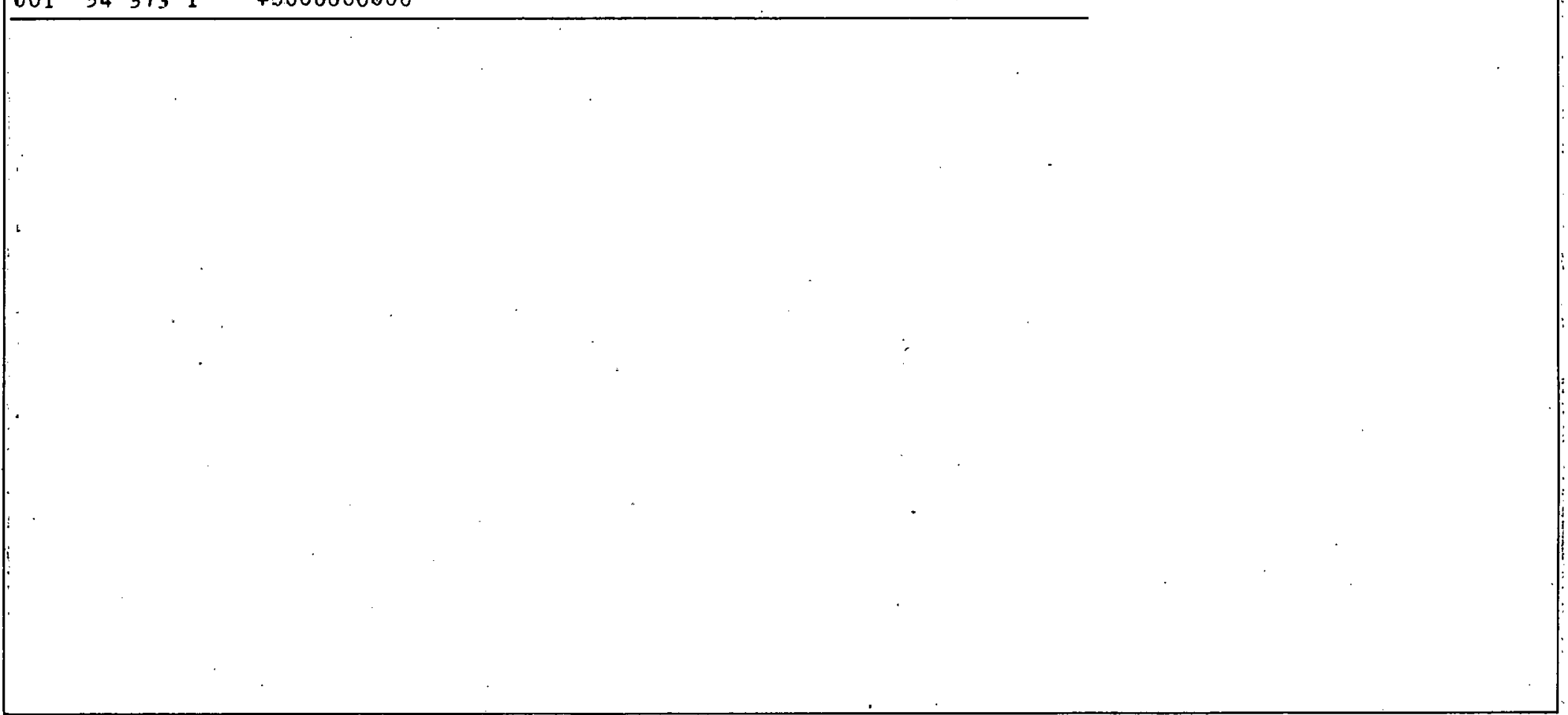




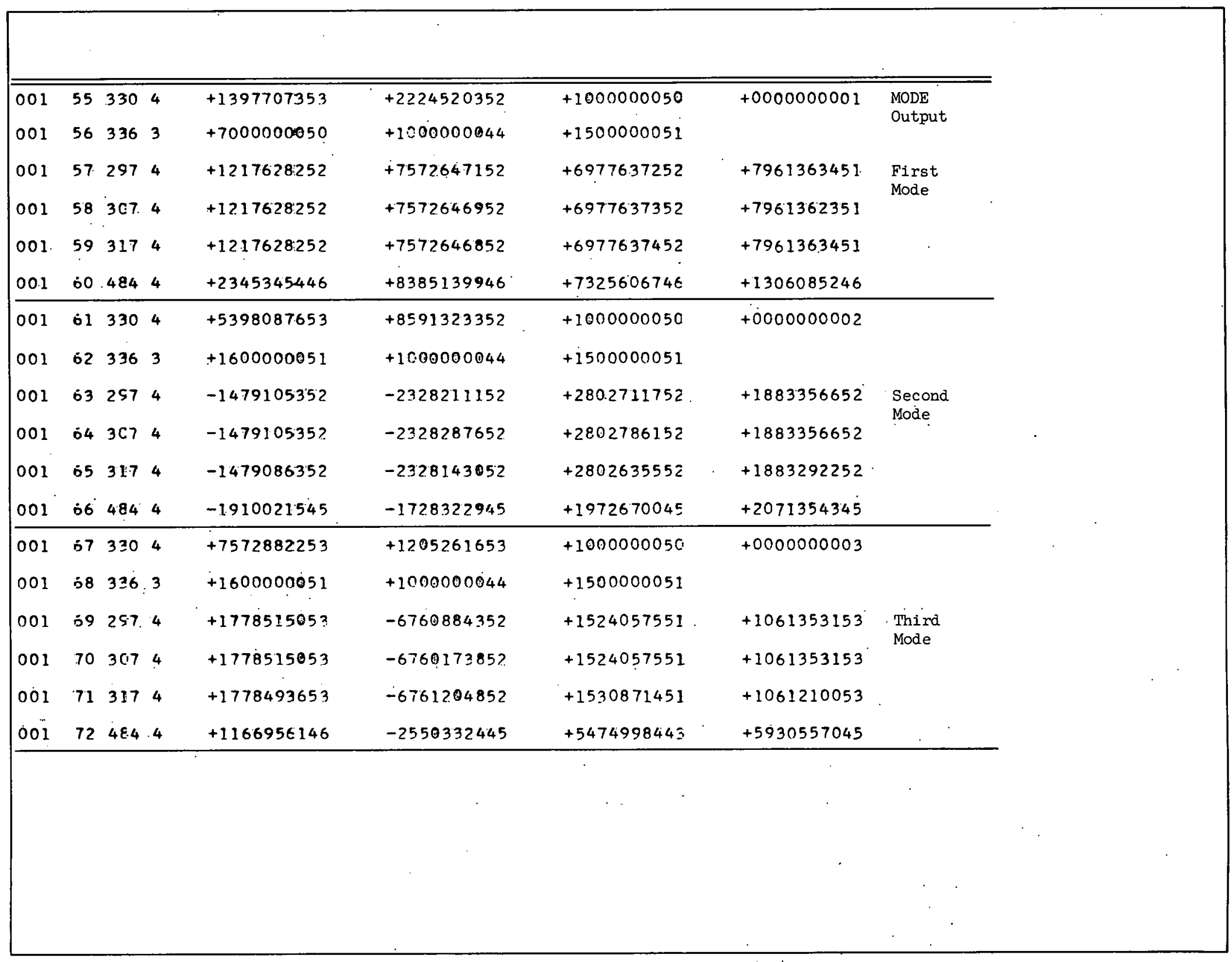




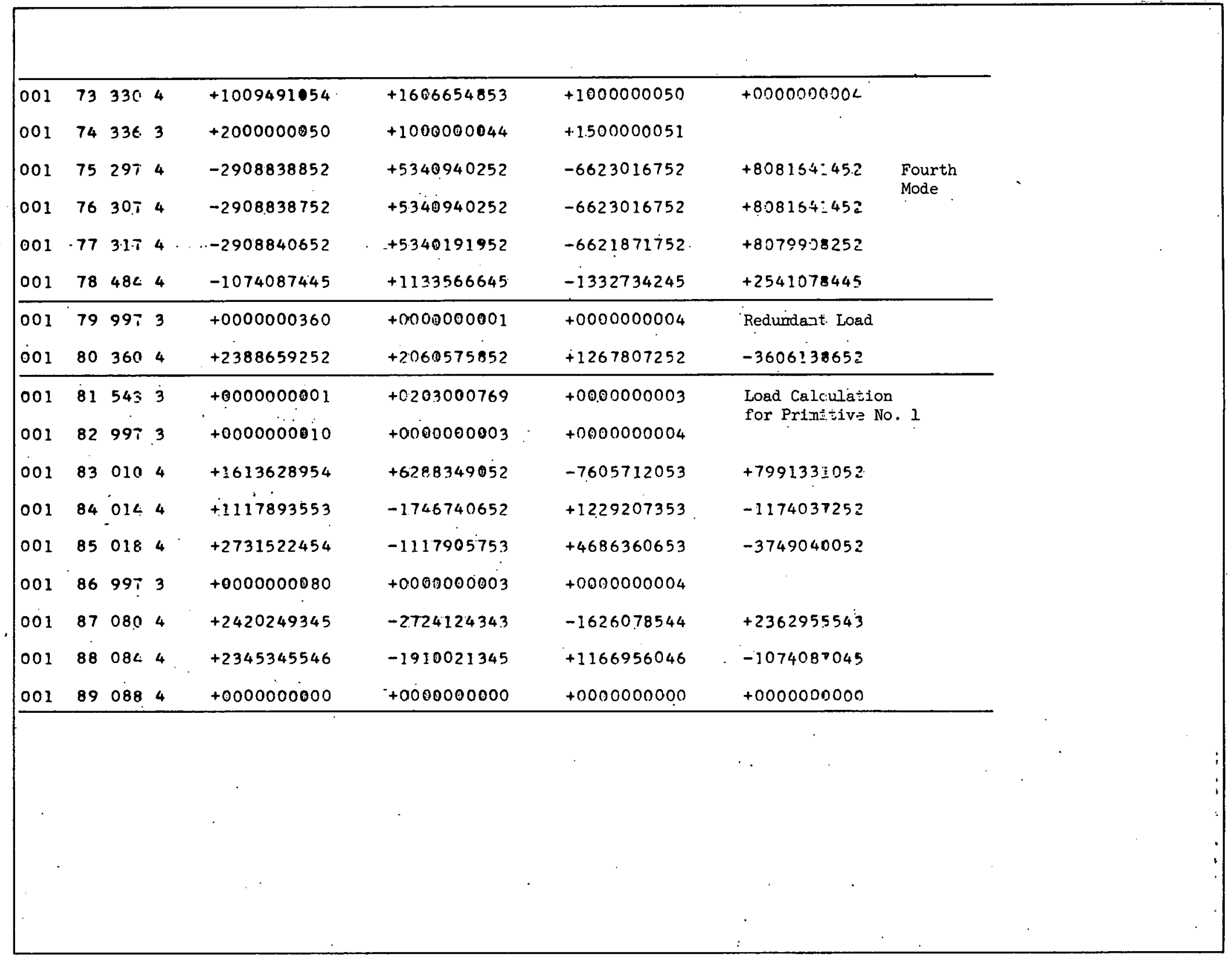




\begin{tabular}{llllllll}
\hline 001 & 90 & 543 & 3 & +0000000005 & +0203000548 & +0000000003 & $\begin{array}{l}\text { Load Calculation } \\
\text { for Primitive No. } 5\end{array}$ \\
001 & 91 & 997 & 3 & +0000000010 & +0000000003 & +0000000004 & \\
001 & 92 & 010 & 4 & +5091973053 & -4322280052 & -2623957653 & -1820713253 \\
001 & 93 & 014 & 4 & +4588978052 & +7421359051 & -1115401452 & -3016378152 \\
001 & 94 & 018 & 4 & +9130808053 & +1536891453 & +4499639653 & +1977959053 \\
001 & 95 & 977 & 3 & +0000000080 & +0000000003 & +0000000004 & \\
001 & 96 & 030 & 4 & +2677560845 & -6047477043 & -1195625545 & -1160228145 \\
001 & 97 & 094 & 4 & +1223955846 & +1284833244 & -5018361645 & -5795942745 \\
001 & 98 & 088 & 4 & +0000000000 & +0000000000 & +0000000000 & +0000000000 \\
\hline
\end{tabular}




\section{ACKNOWLEDGMENT}

The actual preparation and "debugging" of the CTAC and MODE codes were done with the able assistance of $\mathrm{Mr}$. W. D. Long.

\section{REFERENCES}

1. G. Kron, Tensor Analysis of Networks, (New York: John Wiley and Sons, 1939).

2. B. Langefors, "Analysis of Elastic Structures by Matrix Transformation with Special Regard to Semimonocoque Structures," Journal of Aeronautical Sciences, Vol 19 (July 1952), p 451.

3. G. Kron, "Solution of Complex Non-linear Plastic Structures by the Method of Tearing, "Journal of Aeronautical Sciences, Vol.23 (June 1956), p 557.

4. J. H. Argyris, "Energy Theorems and Structural Analysis," Aircraft Eng., Vol 26 (1954), pp 347, 383, and 410; Vol 27 (1955), pp 42, 80, 125, and 145.

5. S. Timoshenko, Strength of Materials, Vol I (Princeton: D. Van Nostrand Co., Inc., 1911).

6. L. A. Pipes, Applied Mathematics for Engineers and Physicists, (New York: McGraw-Hill, 1946).

7. C. M. Friedrich, "Shock Calculations for an Elastic System with Distrihuted Mass, Using the Stảrting Velocity Concept, "WA $\bar{P} \bar{D}-115$ (1954).

8. L. S. Marks, Mechanical Engineerș' Handbook, Fourth Ed. (New York: McGraw-Hill, 1941): 